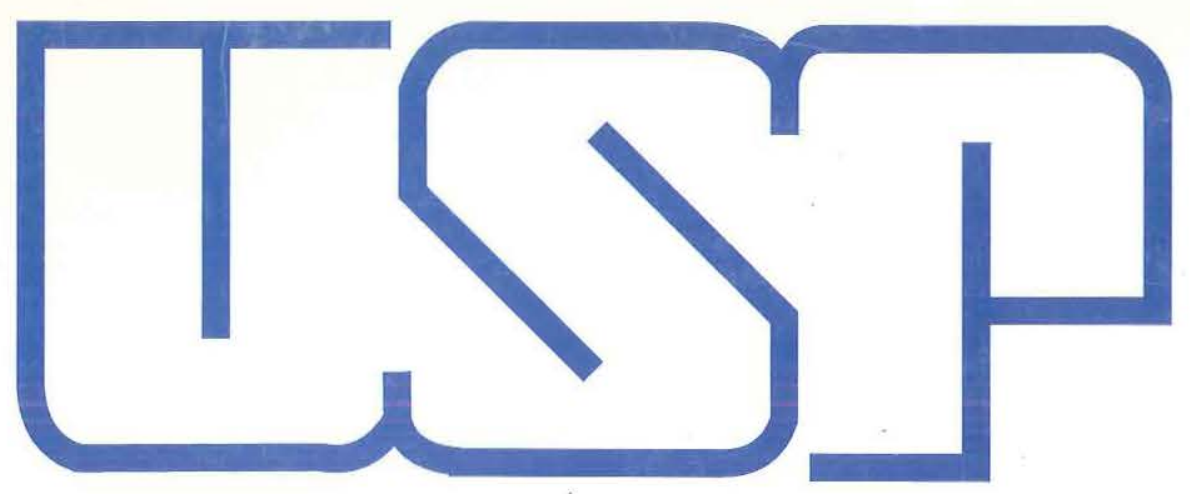

Alterações Provocadas por Esforços Repetitivos na Cartilagem Articular do Joelho Estudo realizado em Ratos Autor: José Carlos Silva Camargo Filho Orientador: Prof. Associado Nilton Mazzer

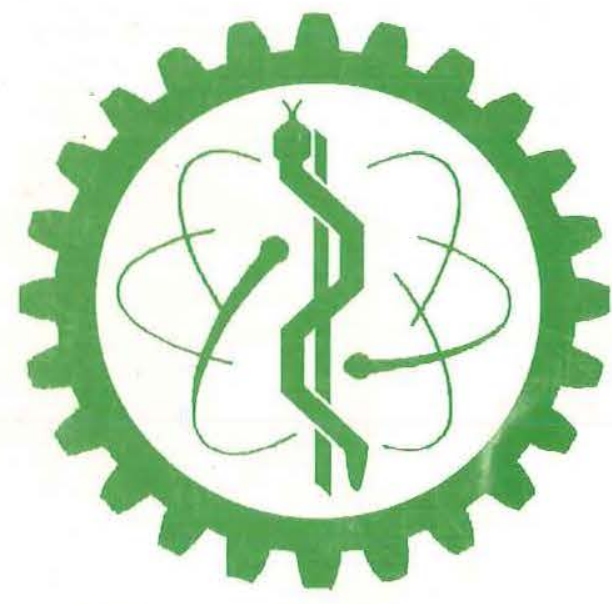

B I OEN GEN H AR I A

USP

Curso de Pós-Graduação Interunidades Bioengenharia

Escola de Engenharia de São Carlos Faculdade de Medicina de Ribeirão Preto Instituto de Química de São Carlos 


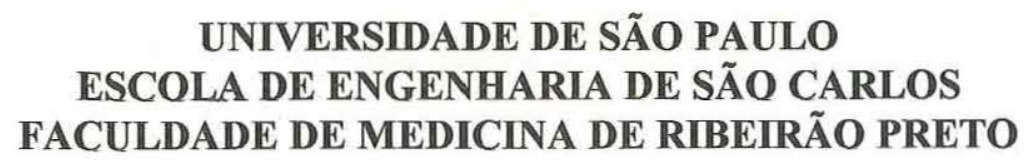

\section{Alterações Provocadas por Esforços Repetitivos na Cartilagem Articular do Joellho Estudo Realizado em ratos}

Dissertação de Mestrado apresentada à Escola de Engenharia de São Carlos e Faculdade de Medicina de Ribeirão Preto da Universidade de São Paulo Área Interunidades de Bioengenharia

Autor: José Carlos Silva Camargo Filho Orientador: Prof. Associado Dr. Nilton Mazzer

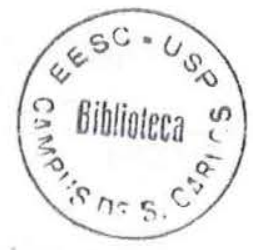

Ribeirão Preto - SP 1998 


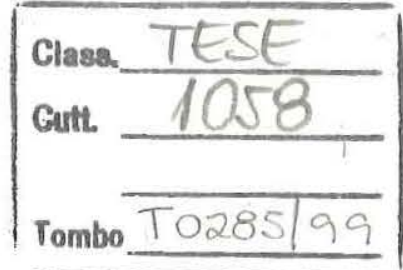

st 1063148

\section{FICHA CATALOGRÁFICA}

611.72 Camargo Filho, José Carlos Silva

C178e "Esforços repetitivos na cartilagem articular do joelho": estudo realizado em ratos_ I José Carlos Silva Camargo Filho: -- Ribeirão Preto, 1998.

83 p.: il.; $31 \mathrm{~cm}$

Dissertação (Mestrado) -- USP, Faculdade de Medicina, Ribeirão

Preto e Escola de Engenharia de São Car1os, 1998.

Orientador: Prof. Dr Nitton Mazzer.

1. Cartilagem Articular. 2. Cartilagem-Degradação. 3. Cartilagem- Stress . 4. Osteoartrite. I. Título 


\section{José Carlos Silva Camargo Filho}

Alterações Provocadas por Esforços Repetitivos na Cartillagem Articular do Joellho Estudo Realizado em Ratos 


\section{DEDクCATÓRM:A}

It minha espasa. Regina Celi.

pela seu entendimenta e dedicaçãa.

pela seu amor demansirado em cada gesta.

na sarrisa e na açãa.

It mens filhos. Thiago. Guilherme e Gabrieh.

pela paciencia, amor e respeita em roda

minha jornada.

It mens pais José Carlos (in memorian)

e Aileen par mostrarem a caminho a sequir.

airravés de seus exemplas de vida.

"... É maravilhosa, Senhor.

solvetuda, ier tãa panca a pedir.

tania a agradecer.

Michel Zuaist 
AGRADECMUENTO ESPECMAL

\author{
Aa Praf. Dr. Niltan Mazzen, \\ que duranie a nealizaçãa deste trabalho. \\ foi mais que um arientador, um verdadeiro \\ amiga. Obrigado pela confianca e seus ensinamentas.
}

"O homem nãa teria alcançado a passúvel.

se repetidas vezes nãa tivesse tentada

a impassível."

Max Weber 


\section{Agradecimentos}

Ao Prof. Dr. Cláudio Henrique Barbieri, pelas suas valiosas sugestões, críticas, incentivo e pela amizade sincera com que me brindou.

Ao Prof. Dr Florêncio Cavalcante Figueiredo, pela acolhida em seu laboratório, pela inestimável colaboração na confecção do material para estudo histológico.

Aos professores da Área Ortopedia e Traumatologia da Faculdade de Medicina de Ribeirão Preto Usp e Bio-Engenharia : Dr. Camilo A. M. Xavier, Dr. José Batista Volpon, Dr. Cleber Jansen Paccola, Dr. Helton A. Defino, Dr. Orivaldo Lopes, Dr. José Batista Portugal Paulin, Dr. José Marcos Alves, Dr. José Romariz Duarte.

Ao grande amigo Dr. Marcelo Nishimura, pela sua acolhida, incentivo e apoio.

Em especial ao amigo para o que der e vier, Prof. Dr. Luiz Carlos Marques Vanderlei, que sem sua ajuda e apoio esse trabalho não seria possível.

Às funcionárias do Departamento de Ortopedia e Traumatologia, Maria de Fátima Feitosa de Lima e Rosa Pereira Brittes Alves, pelo apoio e dedicação.

À Sra. Arlene Silva Roque, ex-secretária do Departamento de Ortopedia e Traumatologia.

À Sra. Marielsa, secretária do Departamento de Bio-materiais.

Ao funcionário da Técnica Cirúrgica e Cirurgia Experimental da FMRP-USP, Sebastião Assis Mazzeto.

Ao funcionário do Laboratório de Bioengenharia Francisco Mazzocato

Às amigas de todo dia, Célia, Denise, Simone, Dalva e Patrícia pelo apoio e incentivo a perseverar neste caminho.

Às funcionárias do Laboratório de Bioquímica da FCT - UNESP de Presidente Prudente, Maria Cristina Perusi e Marilza de Stefani Cardoso, pelo constante auxílio e dedicação.

Ao funcionário e amigo Décio Fregonesi Filho, do Polo Computacional da FCT - UNESP de Presidente Prudente, pela valiosa colaboração prestada a este trabalho.

À Sra. Lídia Ferro, técnica em patologia da UNOESTE, pela valiosa cooperação.

Ao amigo Dr. Luís Mattos, médico patologista, pelo desprendimento e colaboração dedicados.

À CAPES (Coordenação para Aperfeiçoamento de Pessoal de Nível; Superior), através do PICD, pela concessão da bolsa de Mestrado integral, indispensável na realização deste trabalho.

Ao Departamento de Fisioterapia da FCT - UNESP de Presidente Prudente, pelos afastamentos concedidos. 


\section{SUMÁRIO}

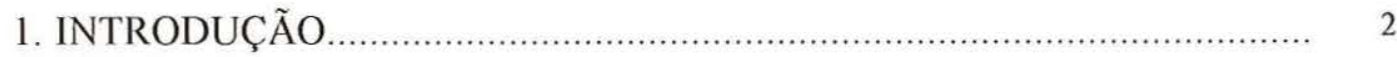

2. REVISÃO BIBLIOGRÁFICA.............................................................. 8

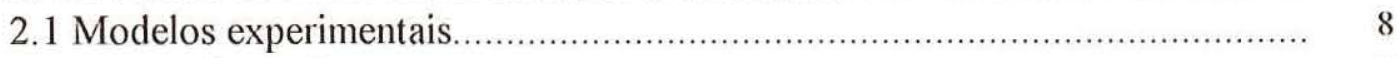

2.2 Lesões da cartilagem............................................................... 11

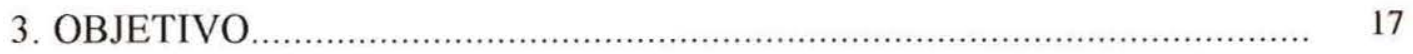

4. MATERIAL E MÉTODOS .................................................................. 19

4.1 Animal de experimentação....................................................................... 19



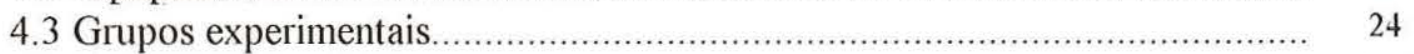

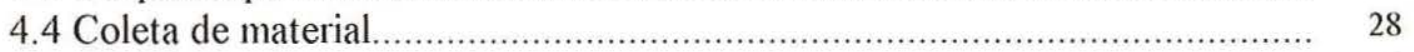

4.5 Padrão de análise estatística................................................................... 31

5. RESULTADOS ................................................................................ 35



5.2 Observações histológicas.................................................................... 36

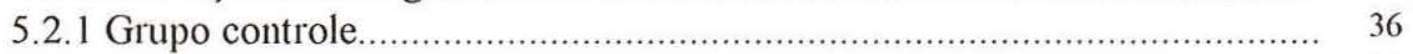

5.2.2 Grupo 1 (movimentos em 80 ciclos e grande amplitude)........................ 36

5.2.3 Grupo 2 (movimentos em 80 ciclos e pequena amplitude) ....................... 38

5.2.4 Grupo 3 (movimentos em 40 ciclos e grande amplitude)........................ 39

5.2.5 Grupo 4 (movimentos em 40 ciclos e pequena amplitude) ....................... 40

5.3 Análise estatística............................................................................. 44

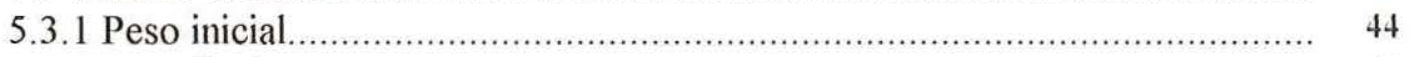

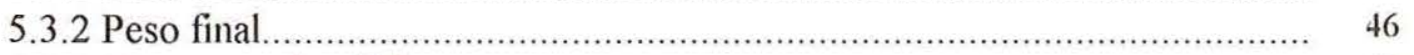

5.3.3 Contagem de células..................................................................... 48

5.3.4 Espessura da cartilagem articular...................................................... 54

6. DISCUSSÃO

7. CONCLUSÃO

8. RESUMO

9. SUMMARY

10. REFERÊNCIAS BIBLIOGRÁFICAS.............................................. 79 
1. INTRODUÇÃO 


\section{INTRODUÇÃO}

Com o crescimento tecnológico, os equipamentos para a prática de exercícios tiveram uma grande evolução. As ofertas de novas máquinas para exercícios e os custos mais baixos tornaram este método acessível à população. A sociedade, através dos meios de propaganda, induziu as pessoas a praticarem exercícios que vão desde uma simples caminhada até a utilização de maquinários com resistência mecânica para a aquisição de massa e força muscular. A preocupação com os benefícios para o sistema muscular e para o sistema cárdio-circulatório era grande, porém as repercussões para o sistema ósteo-articular foram praticamente ignoradas.

SELYE (1936) chamou de "Síndrome Geral de Adaptação" os mecanismos adaptativos de resistência e de defesa do organismo que se manifestam quando o organismo é submetido a um "stress". Essa síndrome possui três estágios. O primeiro estágio, denominado de "reação de alarme", é representado pela resposta inicial do organismo quando exposto a um estímulo ao qual não está adaptado. O segundo estágio é chamado de "fase de resistência", ou seja, quando o estímulo é mantido e ocorre o desenvolvimento de mecanismos adaptativos. Se a adaptação não acontecer, desenvolve-se o terceiro estágio, o " de exaustão", onde o organismo torna-se suscetível a vários distúrbios (SELYE, 1936; VAN de KAR, RICHARDSON-MORTON , RITTENHOUSE, 1991). 
SOKOLOF (1966), citado por KNOPLICK (1975), acredita que uma cartilagem, quando submetida à pressão, apresenta uma deformação imediata devido as alterações da elasticidade da trama fibrosa, ou a expulsão do líquido intersticial ligado às cargas negativas dos grandes polianions da matriz.

A cartilagem hialina possui propriedades de compressibilidade, elasticidade e auto-lubrificação, sendo que a propriedade de elasticidade e as superfícies lubrificadas resistem às forças de friç̧ão responsáveis pela destruição óssea. A cartilagem hialina juntamente com a cápsula e o osso subcondral, são responsáveis pela dissipação da energia do suporte de peso (HOWELL et al., 1976).

Fatores biomecânicos como a exposição ao estresse de carga e atrito, induzem a estímulos que interferem nas propriedades mecânicas da cartilagem articular, levando a uma resposta de adequação ou uma alteração na habilidade de responder as cargas. Atividades imunológicas e bioquímicas, também influenciam a patogenia da osteoartrite (Mc DEVITT, GILBERTSON, MUIR, 1977; BEHRENS, KRAFT, OEGEMA JR., 1989; OLSEN et al., 1991; SMITH et al., 1992; NEWTON et al., 1997). Assim, uma sobrecarga contínua da articulação do joelho predispõe ao aparecimento de doenças como , sinovite, bursite e osteoartrite (HOULI, 1984). 
MANICOURT \& PITA (1988), relataram que pouco se conhece sobre o início da manifestação da osteoartrite em seres humanos, mesmo após estudos de tecidos obtidos durante autópsia e procedimentos cirúrgicos como artrotomias. Estimulados por esses fatos, foram criados diversos modelos experimentais, com o objetivo de simular a doença de humanos. O resultado foi o aprofundamento do conhecimento das alterações físio-patológicas.

HADLEY, BROWN, WEINSTEIN (1990), após estudarem e tratarem por longo tempo pacientes portadores de luxação congênita do quadril, foram os primeiros a demonstrar uma associação entre o excessivo estresse de contato da cartilagem articular e o aparecimento das alterações degenerativas. Para comprovar estes fatos utilizaram um modelo de estresse de contato, computadorizado, para calcular o estresse de contato da cartilagem articular através de radiografias arquivadas.

As forças decorrentes do estresse, quando distribuídas não uniformemente na superfície articular, são responsáveis pelo mecanismo de enfraquecimento da cartilagem (KEMPSON, 1991).

BADER et al. (1992) realizaram estudo experimental com cartilagem articular de humanos, obtida da articulação do joelho e da cabeça femural de pessoas com idade que variavam entre 36 e 86 anos. Foi obtida em exames necroscópicos de rotina, onde a causa morte não afetou as propriedades 
mecânicas da cartilagem articular. Foi utilizado um aparato de compressão uniaxial para aplicação de testes. Concluiram que mesmo sobre estresse inicial, o tecido é metabolizado tão vagarosamente que as mudanças são impossíveis de serem detectadas histologicamente. Esse fato reforçou a teoria da adaptação.

Estima-se que uma articulação do joelho ou do quadril humano, experimenta um milhão de ciclos de carga por ano. Esse estresse, quando associado a um esforço cíclico provoca micro lesões e fadiga na superfície articular, aumentando sua espessura (MOW, RATCLIFFE, POOLE, 1992).

A osteoartrite é a mais comum das doenças reumáticas que afetam o ser humano, possui grande incidência, manifesta-se tanto nos indivíduos do sexo masculino como no feminino, sendo comumente, detectada numa faixa etária acima dos 35 anos (MAXIAN \& BROWN, 1995). Após sua instalação passa a ser irreversível, manifestando-se com sinais de dor articular acompanhada de limitação de movimentos, decorrente da degeneração da cartilagem articular e das mudanças no osso, com formação osteofítica.

Segundo SCHWARTZ, LEO, LEWIS (1994), a degradação da cartilagem articular é a patologia primária de osteoartrite. Essa degradação é caraterizada por uma cisão de superfície da cartilagem articular, que evolui com o atrito para um desgaste da cartilagem, e para esclerose e proliferação do osso. Sua causa é muitas vezes desconhecida, contudo acredita-se que os 
efeitos mecânicos desempenham papel importante no seu desenvolvimento. Não se tem conhecimento se a destruição inicial é decorrente de alguma sobrecarga ou de um enfraquecimento biológico, porém sabe-se que ambos conduzem ao fracasso estrutural no plano microscópico.

Poucas pesquisas foram realizadas para determinar a tolerância ao estresse crônico de contato da cartilagem normal e anormal (MAXIAN \& BROWN, 1995).

Estudos são necessários para verificar os efeitos do uso da cartilagem articular, associa-los a impactos com carga, fator de idade e a manifestação de osteoartrite. 
2. REVISÃO BIBLIOGRÁFICA

2.1 Modelos experimentais

2.2 Lesões da cartilagem 


\section{REVISÃO BIBLIOGRÁFICA}

\subsection{Modelos experimentais}

LANIER (1946) desenvolveu uma máquina para exercitar joelhos de ratos em movimento de flexo-extensão, em regime diário de 1 a 6 horas, com a finalidade de determinar o efeito do exercício sobre a incidência e a gravidade das lesões degenerativas da cartilagem. Concluiu que certos elementos, como células e colágenos, são altamente estáveis, mas outras estruturas, como as proteínas e monossacarídeos, são suficientemente ágeis e metabolicamente ativas para promover renovação parcial.

SEIREG \& GERATH (1975) realizaram o estudo da indução do desgaste cartilaginoso através da aplicação de uma resistência compressiva estática em joelhos de ratos albinos, submetidos a movimentos de vai e vem, por 3 horas diárias durante 14 dias. Não observaram alterações macroscópicas nas articulações nos três primeiros dias. Após os exercícios, os achados foram semelhantes aos joelhos não exercitados dos mesmos espécimes. Com cinco dias relataram uma redução da cartilagem articular, devido a perda de proteoglicanas em todo o joelho. Em tempo superior a cinco dias, observaram alterações focais significativas. 
SILVA, PIVA, FONSECA (1978), desenvolveram uma máquina semelhante, baseada nos princípios do mecanismo biela-manivela para promover o uso excessivo das articulações de pequenos animais, por meio de movimentos de flexo-extensão contínuos. Observaram que os animais sacrifícados entre o primeiro e o terceiro dia de exercícios não apresentaram alterações na cartilagem. Após cinco dias de exercícios, observaram uma perda de proteoglicanas. No décimo dia, relataram uma alteração na espessura da cartilagem.

As alterações da cartilagem articular dependem do tipo de estresse aplicado. VASAN (1983) pesquisou exercícios de correr com cachorros durante oito meses, utilizando uma esteira para corrida com $20^{\circ}$ de inclinação, na qual os animais corriam seis a oito milhas diariamente, durante oito meses. Ao final detectou erosão, cavitações, fibrilação e aumento da síntese de proteoglicanas pelos condrócitos.

KIVIRANTA et al. (1988), estudaram a incidência de lesões na cartilagem decorrentes da atividade de correr em cães da raça Beagles, utilizando uma esteira com $15^{\circ}$ de inclinação, onde os animais corriam cinco dias por semana, em uma velocidade de $4 \mathrm{~km} / \mathrm{h}$ durante 15 semanas. Relatam que os exercícios de correr aumentaram a espessura da cartilagem articular e a concentração de proteoglicanas, principalmente nas regiões sujeitas a cargas elevadas, e que o exercício de correr diariamente não provocou qualquer 
distúrbio na integridade do tecido. Concluiram que para cada tipo de estímulo em excesso tem-se uma resposta específica da cartilagem.

BUCKWALTER (1995) avaliou os efeitos de corridas na cartilagem de cães sob utilização normal moderada ao uso energético. Relata que na corrida moderada, de $4 \mathrm{Km}$ por dia, cinco dias por semana, durante 40 semanas, houve aumento da espessura da cartilagem articular, aumento do conteúdo de proteoglicanas e rigidez da estrutura. Quando da corrida mais enérgica; $20 \mathrm{~km}$ por dia, cinco dias por semana, durante 15 semanas, detectouse diminuição da espessura da cartilagem articular, e também, do conteúdo de proteoglicanas. Corrida enérgica longa; $40 \mathrm{~km}$ por dia, por mais de um ano, induziu à diminuição da concentração de proteoglicanas, rigidez estrutural e estímulo de remodelamento do osso subcondral.

Pesquisadores como LOVÁSZ et al. (1995), passaram a estudar as mudanças histológicas em modelos experimentais com deformidades angulatórias da tíbia. Justificam que na prática clínica a importância da deformidade no desenvolvimento da osteoartrite de joelho ainda é mal definida. No estudo experimental, optaram por um modelo com utilização de artrotomia para produção de uma angulação valga em 30 coelhas adultas. Após a quarta semana de pós operatório, um programa de exercícios foi iniciado, consistindo em encorajar a ambulação fora da gaiola por 1 hora ao dia, cinco dias na semana, durante 12 semanas. Após análise histológica, observaram discreta 
hiperceluridade , desarranjo das colunas estruturais, definindo como mudanças, uma perda suave da cartilagem.

NEWTON et al. (1997), estudaram o efeito de exercícios prolongados nos joelhos de cães, utilizando 11 animais os quais foram exercitados em uma esteira com velocidade de $3 \mathrm{~km}$ por hora, com tempo de 75 minutos, em um período de exercícios de 5 dias por semana, durante 527 semanas, com utilização de jaquetas pesando $130 \%$ do seu peso. Utilizaram, como padrão de controle, cães que permaneceram em atividade liberada dentro de gaiolas. No final do estudo, observaram macroscopicamente que nenhuma das articulações apresentou lesão ligamentar, meniscal, erosões cartilagíneas ou formação de osteófitos. O exame por microscopia ótica não demonstrou evidências de fibrilação, condrócitos modificados e alteração da espessura.

\section{2 - Lesões da cartilagem}

Pesquisadores usaram inúmeros métodos para definir os processos de alteração da cartilagem articular, estudando cada uma das estruturas individualizadas e distintamente. Apontaram seus achados como sendo um fator predisponente, provocando dessa maneira confusões sobre as alterações encontradas. 
HARRISON, SCHAJOWICZ, TRUETA (1953), observaram mudanças degenerativas na articulação de humanos localizadas nas áreas onde não havia incidência de pressão, questionando a possibilidade da cartilagem articular alterar-se pelo pouco uso. Concluiram que o conteúdo de água da matriz foi um componente importante devido suas propriedades físicas e, também, pela capacidade da matriz reter grande quantidade de água.

MANKIN \& LIPPIELLO (1969), realizaram estudos da cartilagem articular de coelhos, através da injeção de marcadores (glicerina e Na2), com objetivo de analisar o metabolismo isotópico, que estabiliza a taxa e distribuição das atividades anabólicas e catabólicas de componentes protéicos e polissacarídeos, além de correlacioná-los ao mecanismo de compensação pelo baixo e alto atrito. Concluiram que "a rápida degradação é uniformemente distribuida através da cartilagem articular e não há evidências de perdas focal ou polarizada", confirmando que a velocidade de intervenção do sistema enzimático é grande, tanto que trabalha abaixo do necessário para compensação dos atritos e que a cartilagem não é inerte, demonstrando uma grande atividade anabólica e catabólica.

Diversas investigações foram realizadas para esclarecer o tipo de estresse e sua relação com as alterações morfológicas e estruturais que possibilitam a manifestação de uma lesão na cartilagem articular (CALANDRÚCIO \& GILMER, 1962; KEMPSON, 1991; BADER et al., 
1992; KOBAYASHI, YONEKUBO, KUROGOUCHI, 1995; MAXIAN \& BRAWN, 1995; PALMER et al., 1995a; PALMER et al., 1995b). As conclusões foram variadas, alguns sugerem que redução ou retirada da tensão da carga também predispõe a processos de degeneração (HARDINGUAN \& FONSANG, 1992; YAN \& KERONG, 1995). Outros sugerem que o aumento da carga possa estimular a síntese de proteoglicanas, para manter uma resistência compressiva (PALMER et al., 1995a; PALMER et al., 1995b).

A lesão ou alteração estrutural da cartilagem pode ser induzida por diferentes meios. Um dos fatores importantes é a bioquímica da cartilagem. A diminuição das proteoglicanas na cartilagem, apesar do aumento da síntese pelos condrócitos, foi exaustivamente estudada por (VASAN, 1983; KIVIRANTA et al., 1987; KIVIRANTA et al., 1988; BEHRENS, KRAFT, OEGEMA JR., 1989; SMITH et al., 1992). Outros componentes bioquímicos, como o ácido hialurônico, o sulfato de keratan e o sulfato de condroitina, são encontrados em um acentuado volume, após aumento do estresse mecânico (KIVIRANTA et al., 1987, 1988).

Pesquisadores relatam que a maior parte desses conflitos de idéias é decorrente da complexidade da formação da cartilagem, pois ela é considerada um tecido conectivo especializado, composto de condrócitos dispostos em camadas, onde sintetizam as proteoglicanas que compõem as matrizes extra-celulares. As proteoglicanas possuem uma especificidade 
decorrente das conexões de proteínas, formando compostos de glicoaminoglicanas, sulfato de Condroitin e sulfato de Keratan; Quando ligados a moléculas de ácido hialurônico são responsáveis pela formação de um agregado de alto peso molecular, com capacidade de unir uma grande quantidade de água. Outro componente, a fibra colágena está disposta em arcos, cobrindo toda superfície do osso subcondral (CALANDRUCCIO \& GILMER JR., 1962; THOMPSON \& HARRY, 1981; KIVIRANTA et al., 1988; HARDINGHAM \& FOSANG, 1992).

THOMPSON \& HARRY (1981), relatam que a quantidade de água é mais alta no animal imaturo e pode representar $80 \%$ do peso em um animal bastante jovem. A quantidade de água na cartilagem humana adulta varia de $65-75 \%$, com um decréscimo associado à idade. Observaram ainda que a concentração de água é maior na superfície. PALMER et al. (1995a), acreditam que as lesões na cartilagem estão relacionadas com o meio líquido, mais especificamente com a constante permeabilidade que permite um movimento de fluido através da matriz.

Relatos dos efeitos do alto e baixo estresse mecânico sobre toda a estrutura da cartilagem articular tem sido amplamente divulgados (THAXTER, MANN, ANDERSON 1965; MCDEVITT, GILBERTSON, MUIR, 1977; KIVIRANTA et al., 1988; MANICOURT \& PITA, 1988; KEMPSON, 1991; SMITH et al., 1992; BUCKWALTER, 1995; LOVÁSZ et 
al., 1995; MAXIAN \& BROWN, 1995; PALMER et al., 1995a; NEWTON et al., 1997). Por outro lado, experimentos que analisam as conseqüências do baixo estresse, seguido de indução ao movimento normal são pouco divulgados (JURVELIN et al., 1989).

O mecanismo de degeneração da cartilagem para alguns autores inicia-se nos condrócitos. Alterações funcionais, influenciadas pela transmissão de forças, podem provocar degeneração dos condrócitos, liberando enzimas. A matriz, em razão dessa liberação, começa a degenerar, formando assim um ciclo, pois a matriz em processo de degeneração interfere na integridade dos condrócitos (HARDINGHAN \& FONSANG, 1992; YAN \& KERONG, 1995). 


\section{OBJETIVO}

O objetivo do trabalho foi estudar as alterações da cartilagem articular do joelho de ratos, provocadas pela variação da amplitude de movimento, pequena $\mathrm{e}$ grande, e da frequência em 40 e 80 ciclos por minuto, utilizando-se uma máquina de movimentação de flexo-extensão contínua passiva. 
4. MATERIAIS E MÉTODOS

4.1 Animal de experimentação

4.2 Equipamento

4.3 Grupos experimentais

4.4 Coleta de material

4.5 Padrão de análise estatística 


\section{4 - MATERIAIS E MÉTODOS}

\section{1- Animal de experimentação}

Foram utilizados 24 animais da linhagem Wistar (Rattus Norvergicus, var. albina, Rodentia, Mammalia), machos, com peso médio de 250 gramas, obtidos no Biotério Central da UNESP, Campus de Botucatu.

Os animais foram divididos aleatoriamente em grupos de três para cada gaiola plástica. Permaneceram, durante o experimento, no Biotério da Faculdade de Ciências e Tecnologia - UNESP, Campus de Presidente Prudente, onde foram hidratados e alimentados com água e ração padrão para roedores ad libitum, mantidos sob temperatura de $23^{\circ} \mathrm{C}$, com ciclo de luminosidade, claro e escuro, de 12 horas. Os animais foram pesados no $1^{\circ}$ dia do experimento e após a última série de exercícios.

\section{2- Equipamento}

Foi utilizada uma máquina de exercícios (SILVA, PIVA, FONSECA, 1978) cujo componente principal foi construído no Departamento de Engenharia Mecânica da UNB - Brasília, sendo o restante do aparelho e sua montagem realizados no SENAI de Presidente Prudente. Essa máquina foi 
idealizada para experimentos em pequenos animais, sendo elaborada em duas partes: uma fixa e outra móvel (esquema 1), as quais são montadas sobre uma plataforma (esquema 2) e dirigida por um motor.

A unidade fixa, é formada por duas partes paralelas montadas independentemente (A). Cada parte tem a forma de foice. A parte proximal é reta e a parte distal curva. A parte reta é presa por uma chapa de duraluminio, a qual permite que a unidade seja fixada na plataforma por parafusos. Essas chapas têm, sobre ambos os lados, um pino de metal com uma cabeça perfurada para transpassar um fio de aço, o qual é fixado na coxa do animal. A parte curva da foice tem dentro da circunferência um encaixe central o qual serve como guia para a parte móvel. Esses traçados são de três centímetros e foram designados para permitir um grau máximo de flexão e extensão da articulação.

A parte móvel é do tipo manivela e tem uma cabeça em forma de "U", feita de duas partes laterais unidas por um componente central (B). A parte lateral da manivela tem em seu final distal um pino cilíndrico removível, o qual se ajusta dentro do encaixe que orienta os movimentos quando o motor é acionado. O pino tem um furo central para introdução do fio de aço, mantido em posição pelo mesmo. O corpo do cabo da manivela é fixado na cabeça por parafusos e sua parte distal é conectada no braço de uma roldana.

Esse braço tem perfurações que permitem ao cabo da manivela assumir três posições diferentes, a fim de possibilitar variações na amplitude

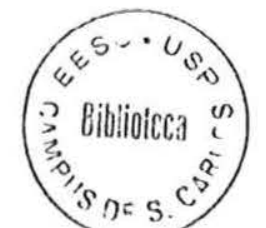


dos movimentos. A perfuração distal permite um movimento amplo da parte móvel (manivela) em relação à unidade fixa em forma de foice, sendo este movimentos definido como de grande amplitude. A perfuração proximal restringe o movimento da parte móvel (manivela) em relação à unidade fixa em forma de foice, sendo este movimento definido como de pequena amplitude. Os eixos dessa roldana são montados sobre uma base de metal, (C), e seu braço é ativado pela correia do motor na roldana. Os movimentos são dirigidos por um motor e a velocidade é controlada por um reostato. 

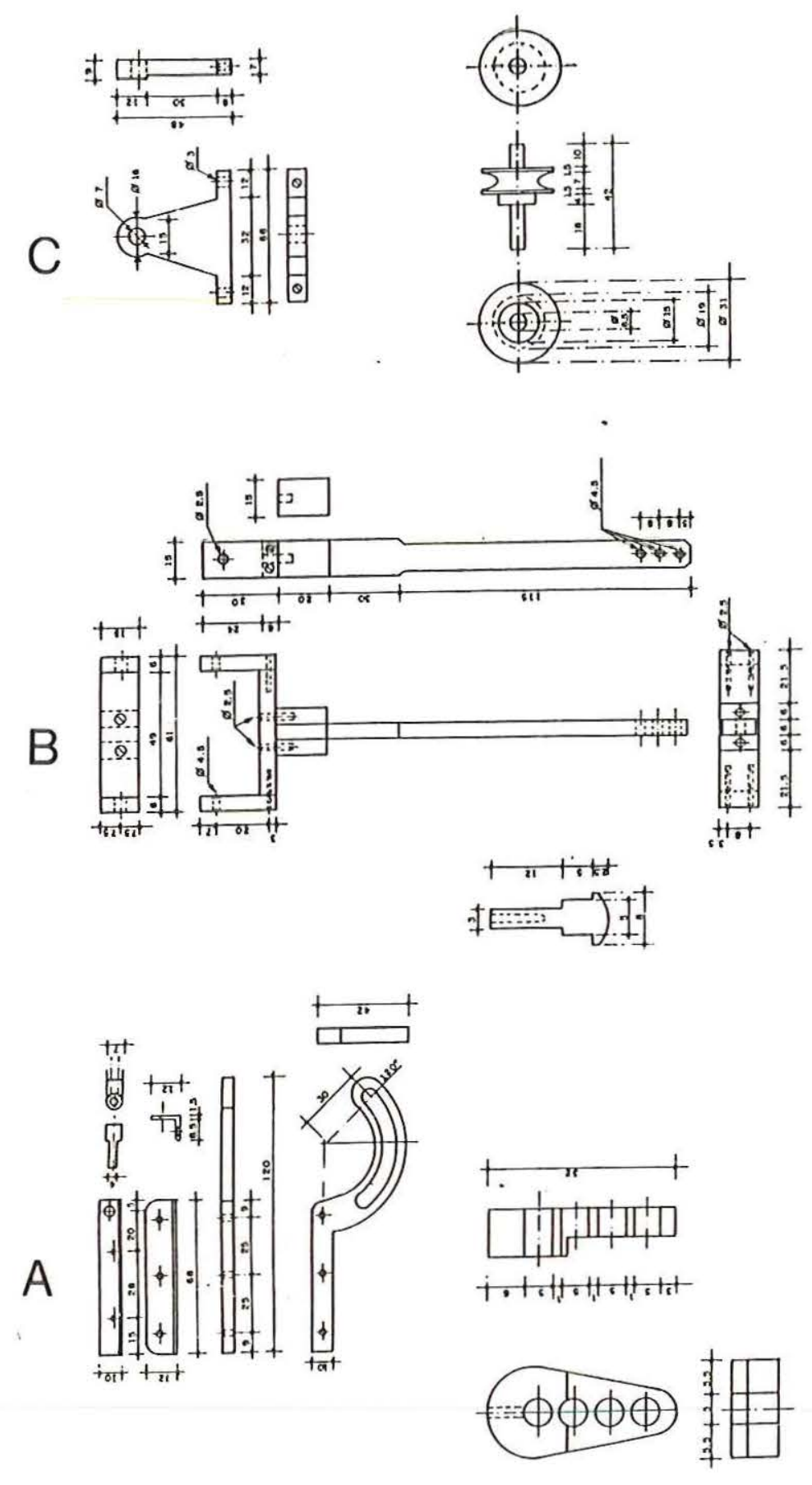

Fig. 1 - Representação diagramática da máquina, mostrando as duas partes: fixa e móvel. A unidade fixa é formada por duas partes paralelas, montadas independentemente (A). A parte móvel é composta por duas partes laterais, unidas por um componente central (B). A base de metal do aparelho é composta por polias (C). 


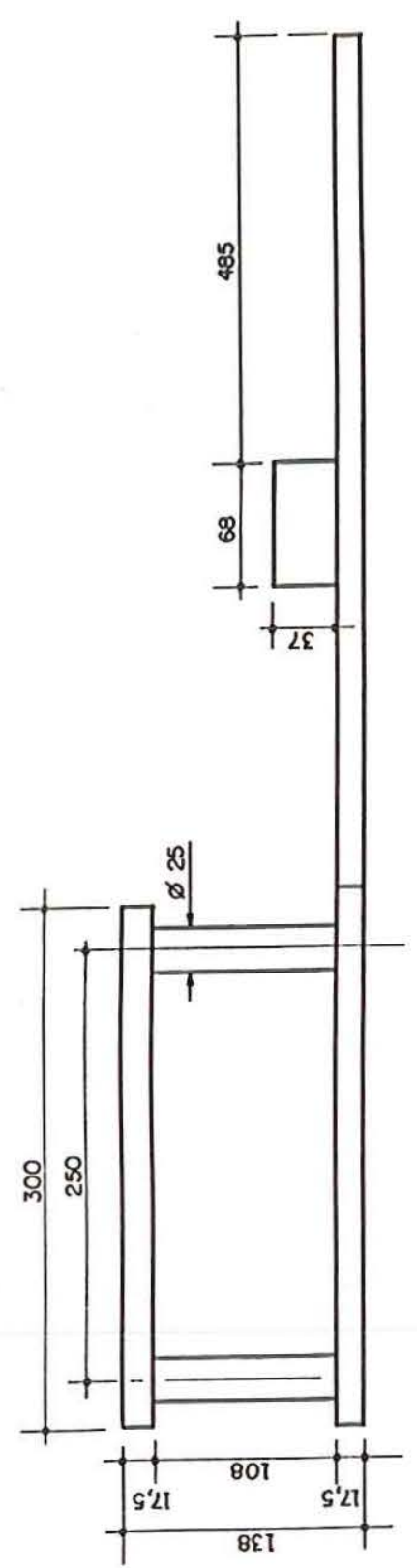

A



B

Fig. 2 - Representação da plataforma da máquina: (A) vista lateral, (B) vista frontal. 


\section{3 - Grupos Experimentais}

Os animais foram divididos em quatro grupos, contendo cada grupo seis elementos. Estes grupos foram designados como: grupo 1 (G1), grupo 2 (G2), grupo 3 (G3) e grupo 4 (G4), respectivamente.

No G1 e G2, os animais foram distribuídos em gaiolas devidamente identificadas, sendo que cada uma delas continha um grupo de amplitude diferente, ou seja, um grupo de grande amplitude e outro de pequena amplitude, os quais desempenharam movimentos com 80 ciclos por minuto. Cada animal foi exercitado diariamente durante um período de 1 hora, por duas semanas consecutivas.

Tratamento idêntico foi administrado ao G3 e G4, diferenciado dos dois primeiros grupos, somente pela alteração da velocidade de movimento para 40 ciclos por minuto.

Utilizou-se como anestésico o thiopental (Tiopental Sódico) ${ }^{1}$, com aplicação peritonial, na proporção de $0,5 \mathrm{ml}$ por $100 \mathrm{~g}$ de peso do animal, aguardando-se um tempo para a instalação do plano de anestesia.

\footnotetext{
${ }^{1}$ Tiopental, Cristália
} 
Todos os animais foram colocados em decúbito dorsal na plataforma da máquina (figura 3-A). Na face posterior do terço proximal da coxa, foi transpassado um fío de aço de $1,1 \mathrm{~mm}$ de diâmetro, através dos tecidos moles, com as pontas introduzidas nos orifícios dos pinos cilíndricos e presos na parte reta da chapa de duraluminio fixada na plataforma do aparelho. Outro fio de aço do mesmo diâmetro foi transpassado ao nível do tendão de Aquiles e suas pontas introduzidas dentro do orifício central dos pinos, em movimento da manivela (figura 3-B).

Com ativação da máquina, o joelho direito de cada animal executou movimentos de flexo-extensão contínua na frequência específica de cada grupo (figura 3-C). O joelho contra lateral (esquerdo), não foi exercitado, servindo apenas como controle.

Procurando evitar resistência por parte do animal, por diminuição do efeito anestésico durante o programa de exercícios na máquina, a cada reação foi utilizado um chumaço de algodão embebido em éter sulfúrico para mantê-lo em um plano de sedação (figura 3-D ). Com o término de cada sessão, o animal foi novamente recolocado na gaiola a que pertencia o seu grupo de frequência e amplitude. O esquema de trabalho dos animais obedeceu o seguinte cronograma: no período matinal foi trabalhada a frequência de 80 ciclos por minuto com exercícios em grande e pequena amplitude, no período da tarde trabalhou-se a frequência de 40 ciclos em grande e pequena amplitude. 
Após os 15 dias esses animais foram sacrificados, utilizando-se inalação de éter após o término das sessões, respeitando a seqüência do cronograma de trabalho. 

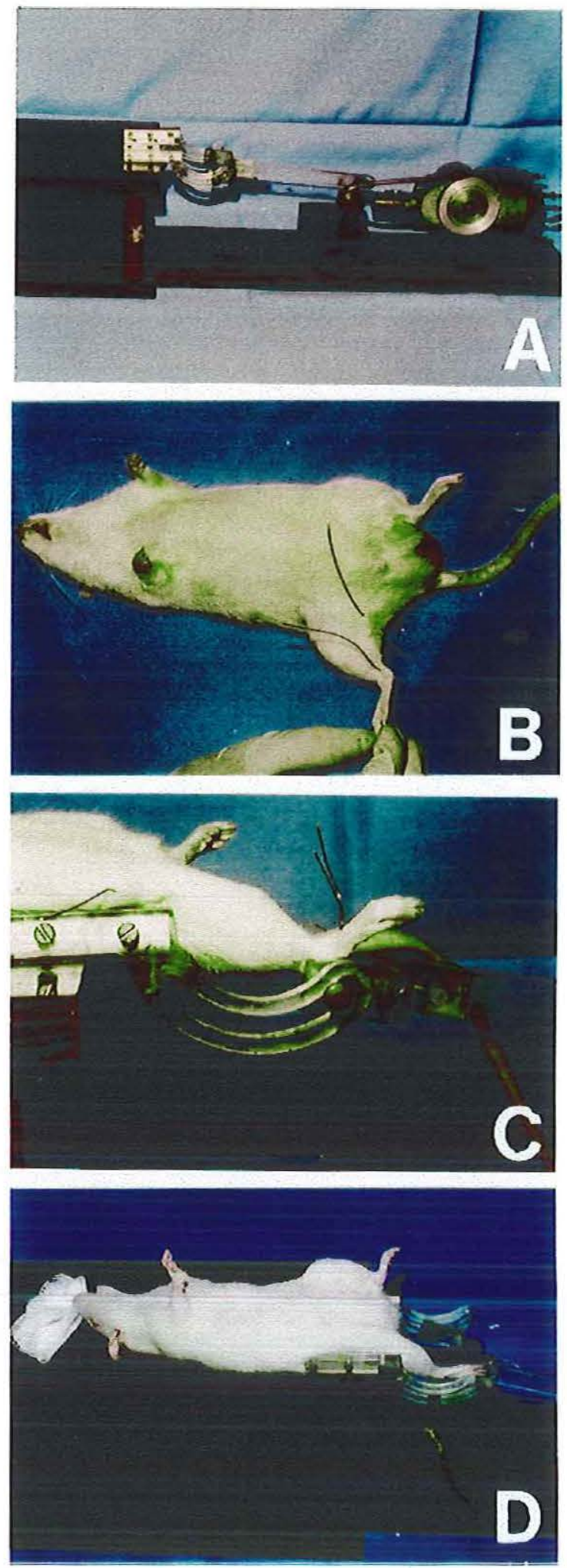

Fig. - 3 Adaptação do animal à máquina de exercícios: (A) - Máquina de exercícios de flexo-extensão; (B) - Colocação dos fios de aço no animal para fixação na máquina; (C) - Pata direita fixada à máquina; (D) - Animal posicionado para seção de exercícios. 


\section{4 - Coleta do material}

Para a retirada da articulação, foi feita uma incisão lateral desde a raiz da coxa até a articulação do tornozelo. Após, toda a musculatura envolvida foi rebatida, sendo cortados os ligamentos laterais e aberta a cápsula, ficando exposta a articulação do joelho (figura 4-A).

Posteriormente, com seç̧ão dos ligamentos cruzados, o fêmur foi desarticulado da tíbia (figura 4-B), posteriormente seccionado o fêmur, sendo em seguida retirado os côndilos, utilizando-se um osteótomo (figura 4-C). A espécime foi colocada em frascos de vidro, contendo soro fisiológico, devidamente identificados com siglas correspondentes aos grupos (figura 4-D).

Imediatamente, as espécimes foram encaminhadas para o Laboratório de Histologia, para a fixação. O método utilizado para fixação foi o de formol tamponado, ph 7, por um período de 12 horas e a descalcificação induzida pelo método de Cajal, que é constituído de aldeído fórmico (37-40) $14 \mathrm{ml}$, água destilada $86 \mathrm{ml} \mathrm{e}$ ácido nítrico $3 \mathrm{ml}$, por um período de 24 horas.

Posteriormente, através de um corte no plano sagital, foram separados os côndilos direito e esquerdo (figura 5-A e 5-B). Foi realizada a desidratação pelo método alcoólico crescente, seguindo-se a diafanização por xilol e inclusão em blocos de parafina. 
As peças foram cortadas no sentido do plano sagital no Laboratório de Patologia da Faculdade de Medicina - USP de Ribeirão Preto, com micrótomo rotatório pelo método semi-seriado, com espessura de $5 \mu \mathrm{m}$, e coradas pelo método hematoxilina-eosina. Uma área quadrada de $1 \mathrm{~mm}$, situada no seguimento posterior do côndilo lateral direito foi definida e analisada em fotomicroscópio com aumento de $100 \mathrm{X}$ para mensuração da espessura e $450 \mathrm{X}$ para contagem do número de células (figura 6). Utilizou-se uma lâmina reticulada composta de 10 câmaras no sentido horizontal e 10 câmaras no sentido vertical, perfazendo um total de 100 câmaras, medindo cada uma $0,05 \mathrm{~mm} \times 0,05 \mathrm{~mm}$ para a contagem do número de células e medida de espessura. A lâmina reticulada foi medida utilizando-se uma régua "ERNEST LEITZ" - WTZELAR com $2 \mathrm{~mm}$ linear e intervalo de $0,01 \mathrm{~mm}$. 

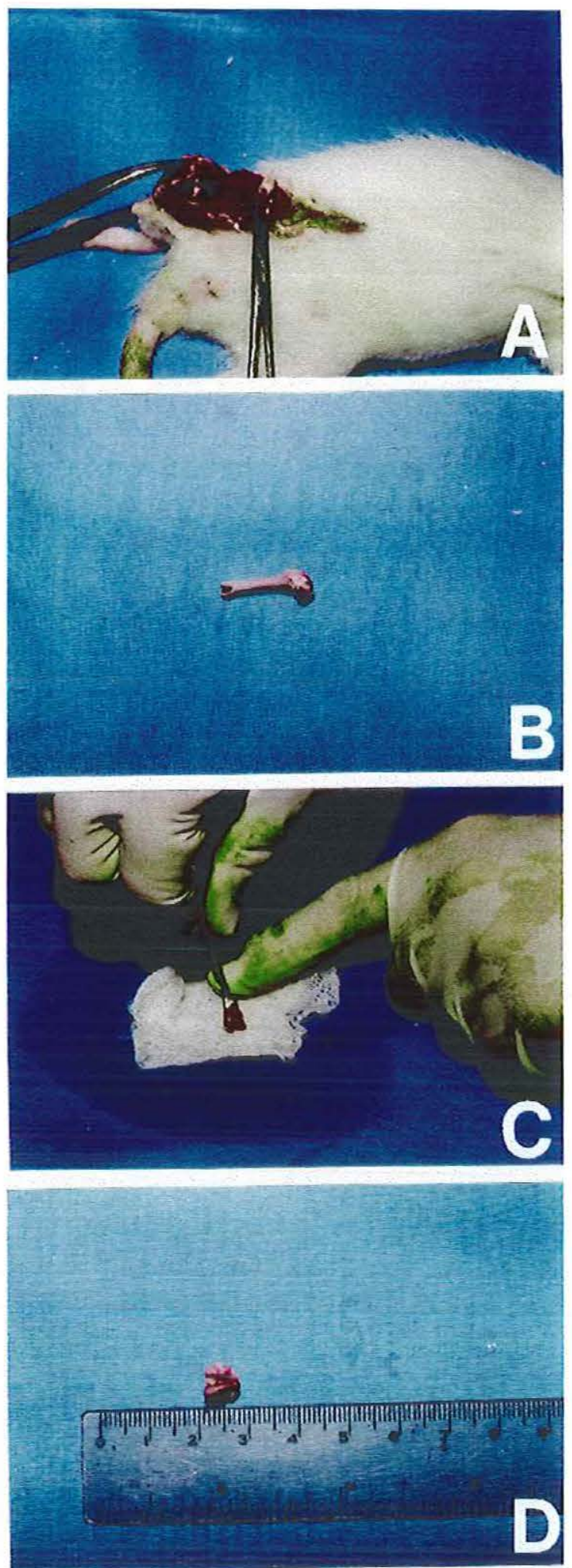

Fig. 4 - Procedimento cirúrgico para retirada da cartilagem articular do joelho de rato: (A) Ressecção da musculatura, capsula-articular e ligamentos; (B) - Fêmur desarticulado; (C) - Retirada dos côndilos; (D) - Visão macroscópica dos côndilos. 


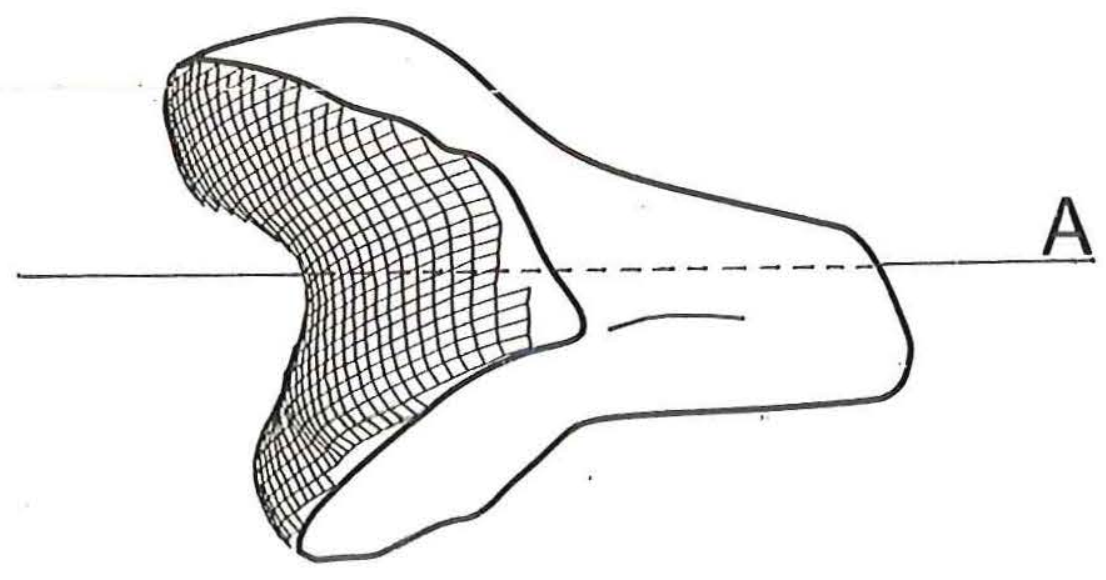

A

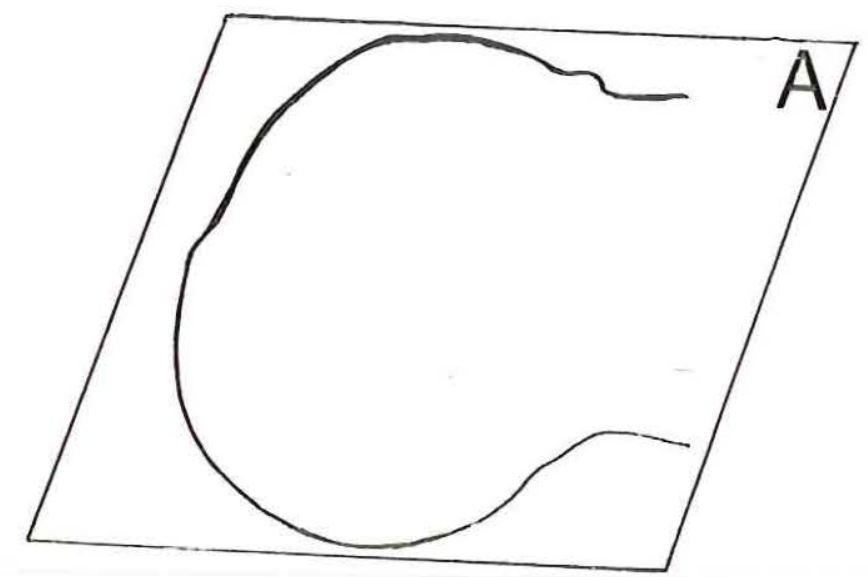

B

Fig. 5 - (A) Representação da seç̧ão dos côndilos do fèmur direito (B) Representação do plano sagital utilizado para os cortes histológicos do côndilo lateral do fêmur direito. 


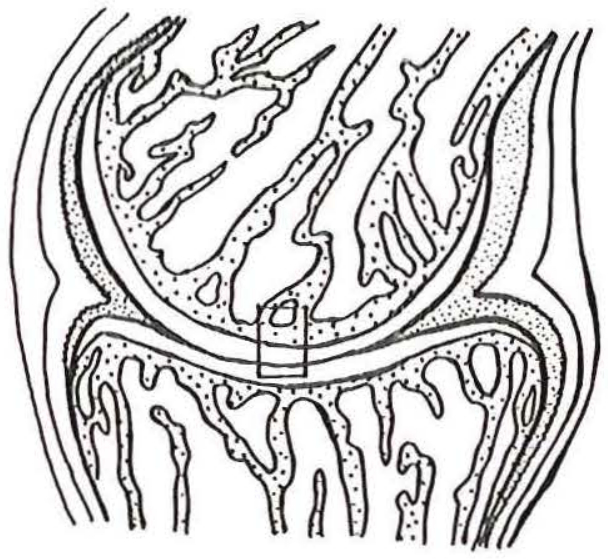

Fig. 6 - Representação da área definida para análise microscópica da cartilagem articular do côndilo lateral do joelho direito 


\section{5 - Padrão de análise estatística}

Com o objetivo de comparar os resultados obtidos nos diferentes grupos experimentais (exercícios com 80 ciclos por minuto em grande amplitude, exercícios com 80 ciclos por minuto em pequena amplitude, exercícios com 40 ciclos por minuto em grande amplitude, exercícios com 40 ciclos por minuto em pequena amplitude), foram avaliadas as médias de peso dos ratos, as medidas de espessura e o número de células da cartilagem.

A análise estatística empregada para tais comparações foi de variância, seguida da aplicação do teste de TUKEY. O objetivo desses testes foi determinar se os exercícios com frequência de 80 e 40 ciclos por minuto em grande e pequena amplitude resultaram em mudanças significativas da espessura e número de células em relação ao grupo controle. As diferenças foram consideradas significantes para $\mathrm{p}<0,05$. 
5. RESULTADOS

5.1 Generalidades

5.2 Observações histológicas

5.2.1 Grupo controle

5.2.2 Grupo 1 (movimentos em 80 ciclos/min. e grande amplitude)

5.2.3 Grupo 2 (movimentos em 80 ciclos $/ \mathrm{min}$. e pequena amplitude)

5.2.4 Grupo 3 (movimentos em 40 ciclos $/ \mathrm{min}$. e grande amplitude)

5.2.5 Grupo 4 (movimentos em 40 ciclos/min. e pequena amplitude)

5.3 Análise estatística

5.3.1 Peso inicial

5.3.2 Peso final

5.3.3 Contagem de células

5.3.4 Espessura da cartilagem articular 


\section{RESULTADOS}

\section{1- Generalidades}

Os animais que receberam dose adequada $(0,5 \mathrm{mg}$ para cada $100 \mathrm{~g}$ de peso corporal) de solução de tiopental sódico, toleraram bem a anestesia, sendo que apenas dois animais não resistiram (um animal pertencente ao grupo exercitado com velocidade de 80 ciclos e grande amplitude, e outro pertencente ao grupo exercitado com velocidade de 40 ciclos e pequena amplitude). Ocasionalmente foi necessária a utilização de éter para a manutenção do plano anestésico até o término do exercício.

Nas horas seguintes ao procedimento, já conseguiam locomoverse nas gaiolas e nos quatro primeiros dias a marcha era aparentemente normal, sendo que após esses dias a grande maioria tinha dificuldade para a marcha, observando-se após dez dias de exercícios, um aumento da circunferência do joelho direito.

Não foi verificada nenhuma intercorrência pela passagem do fio de aço no tendão de Aquiles e na coxa. Após o $9^{\circ}$ dia de experimento notou-se a formação de um pertuito no tendão de Aquiles, facilitando assim a introdução 
do fio de aço. Ao nível da coxa não houve uma boa definição do orifício, mas a transfixação do fio foi realizada com facilidade.

\section{2 - Observações histológicas}

\subsection{1 - Grupo controle}

O joelho contra-lateral não exercitado de cada animal foi definido como referência de controle. As análises histológicas demonstraram que as células apresentaram distribuição uniforme, tanto na superfície como na zona média e profunda da cartilagem articular, com aspecto morfológico característico de cada zona (figuras 7-A e 8-A). A espessura da cartilagem articular foi mensurada entre a linha que limita superiormente a zona calcificada e a superfície articular (figuras 7-B e 9-A).

\subsection{2 - Grupo 1 (Movimentos em 80 ciclos p/ minuto e grande amplitude)}

Em todos os animais desse grupo foi observado aumento do número de células no joelho exercitado em relação ao joelho controle (quadro 1). A camada superficial de células, horizontalmente dispostas, alongadas e compactas, estava sempre presente e a maioria das cartilagens analisadas encontrava-se mais espessa, com duas ou três camadas de condrócitos. Encontrou-se também células esféricas entre as células chatas que compõem a zona tangencial. Foi verificada uma densidade maior de células na zona média, especificamente na região de transição entre ela e a zona superficial. Observou-se ainda, nessa região, que a maioria das células não estava regular, encontrando-se agrupadas em número de até cinco células. Nessa região as células apresentavam um tamanho bem maior que as contidas nas outras zonas. 
A lacuna entre a zona profunda e a zona calcificada estava diminuída pela presença de número maior de células (figura 8-C).

A espessura da cartilagem articular estava aumentada da medida perpendicular da superfície articular até a linha superior da zona calcificada. Não foram mensuradas individualmente as zonas: superficial, média e profunda, o que dificultou um relato mais detalhado e minucioso do acréscimo de espessura (figura 9-C).

Quadro 1- Valores da contagem de condrócitos e medida de espessura da cartilagem articular $(\mu \mathrm{m})$ do côndilo femural submetidos a movimentos de flexo extensão contínua em 80 ciclos/min. em grande amplitude e do controle.

\begin{tabular}{|c|c|c|c|c|}
\hline & \multicolumn{2}{|c|}{$\begin{array}{c}\text { Contagem de células } \\
\text { 80 ciclos grande amplitude }\end{array}$} & \multicolumn{2}{c|}{$\begin{array}{c}\text { Medida de Espessura } \\
\text { 80 ciclos grande amplitude }\end{array}$} \\
\hline & D & E & D & E \\
\hline Rato 1 & 136 & 80 & 190 & 90 \\
\hline Rato 2 & 147 & 57 & 200 & 100 \\
\hline Rato 3 & 142 & 78 & 210 & 100 \\
\hline Rato 4 & 101 & 60 & 200 & 100 \\
\hline Rato 5 & 132 & 53 & 230 & 120 \\
\hline Rato 6 & $\mathrm{XXX}$ & $\mathrm{XXX}$ & $\mathrm{XXX}$ & $\mathrm{XXX}$ \\
\hline
\end{tabular}




\subsubsection{Grupo 2 (Movimentos em 80 ciclos p/minuto e pequena amplitude)}

Foi observado aumento do número de células da cartilagem articular do joelho exercitado, em todos os animais pertencentes a esse grupo, quando comparados ao seu respectivo controle. Confrontando este resultado com o apresentado no grupo 1, fica demonstrado que houve um decréscimo do número de células, visualizado na tabela 3 e quadro 2 . Não se tem uma visualização distinta quanto a diferença achada nesse grupo 2 em relação ao grupo 1, observando-se apenas que a densidade de células está mais concentrada na zona média, decrescendo em relação à zona profunda, visualizando, também, grupos perpendiculares à superfície, tomando forma de colunas.

Em relação à medida de espessura, observou-se um aumento significante em relação ao seu respectivo controle, mas não evidenciando diferença em relação ao grupo 1 , o que pode ser visualizado na tabela 5 e quadro 2.

Quadro 2- Valores da contagem de células e medida de espessura da cartilagem articular $(\mu \mathrm{m})$ dos côndilos femurais de ratos submetidos a movimentos de flexo-extensão contínua em 80 ciclos p/ minuto e pequena amplitude.

\begin{tabular}{|c|c|c|c|c|}
\hline & \multicolumn{2}{|c|}{$\begin{array}{c}\text { Contagem de células } \\
\text { 80 ciclos pequena amplitude }\end{array}$} & \multicolumn{2}{c|}{$\begin{array}{c}\text { Medida de espessura } \\
\text { 80 ciclos pequena amplitude }\end{array}$} \\
\hline & D & E & D & E \\
\hline Rato 1 & 127 & 50 & 190 & 100 \\
\hline Rato 2 & 110 & 68 & 180 & 120 \\
\hline Rato 3 & 118 & 63 & 220 & 80 \\
\hline Rato 4 & 95 & 55 & 190 & 110 \\
\hline Rato 5 & 81 & 54 & 200 & 100 \\
\hline Rato 6 & 99 & 70 & 200 & 80 \\
\hline
\end{tabular}




\subsection{4 - Grupo 3 (Movimentos com 40 ciclos p/ minuto e grande amplitude)}

O número de células encontradas em todo o seguimento definido para estudo da cartilagem articular foi maior que o encontrado no joelho controle (quadro 3 ) e menor que no grupo 1 e 2 , visualizado nas tabelas 3 e 4 . As células da zona superficial encontravam-se horizontalmente dispostas em duas camadas. A densidade celular mostrou-se menor na zona intermediária e profunda, poucas células agrupadas e em número de 2 a 3 , delimitando espaços vazios maiores na matriz. A distribuição das células estava em um padrão morfologicamente semelhante ao normal.

Quanto à medida de espessura, encontrou-se aumento em relação ao respectivo controle (quadro 3), não sendo estimada por zonas, como já citado anteriormente.

Quadro 3- Valores da contagem de células e medidas de espessura da cartilagem articular $(\mu \mathrm{m})$ dos côndilos femurais de ratos submetidos a movimentos de fle-extensão contínua em 40 ciclos p/ minuto e grande amplitude.

\begin{tabular}{|c|c|c|c|c|}
\hline & \multicolumn{2}{|c|}{$\begin{array}{c}\text { Contagem de células } \\
\text { 40 ciclos grande amplitude }\end{array}$} & \multicolumn{2}{c|}{$\begin{array}{c}\text { Medida de espessura } \\
\text { 40 ciclos grande amplitude }\end{array}$} \\
\hline & D & E & D & E \\
\hline Rato 1 & 109 & 56 & 190 & 100 \\
\hline Rato 2 & 50 & 60 & 180 & 110 \\
\hline Rato 3 & 77 & 58 & 190 & 110 \\
\hline Rato 4 & 66 & 57 & 170 & 90 \\
\hline Rato 5 & 97 & 70 & 190 & 90 \\
\hline Rato 6 & 87 & 52 & 140 & 110 \\
\hline
\end{tabular}




\subsection{5 - Grupo 4 (Movimentos com 40 ciclos p/minuto e pequena amplitude)}

Nesse grupo como nos outros, foi observado um aumento do número de células em relação ao respectivo controle (quadro 4). Foi percebido que as células mantiveram um padrão igual ao controle, visualizado pelos condrócitos planos da zona superficial, também pelo aspecto circular das células na zona intermediária com distribuição regular pelas camadas (figura 8-B).

Houve aumento da espessura na medida perpendicular da superfície articular até a linha superior da zona calcificada quando comparada com o seu controle. Percebeu-se que a zona superficial teve uma diminuição na sua espessura, em relação aos outros grupos (figura 9-B).

Quadro 4- Valores da contagem de células e medida de espessura da cartilagem articular $(\mu \mathrm{m})$ dos côndilos femurais de ratos submetidos a movimentos de flexo-extensão contínua em 40 ciclos p/minuto e pequena amplitude.

\begin{tabular}{|c|c|c|c|c|}
\hline & \multicolumn{2}{|c|}{$\begin{array}{c}\text { Contagem de células } \\
\text { 40 ciclos pequena amplitude }\end{array}$} & $\begin{array}{c}\text { Medida de espessura } \\
\text { ciclos pequena amplitude }\end{array}$ \\
\hline & D & E & D & E \\
\hline Rato 1 & 62 & 54 & 160 & 120 \\
\hline Rato 2 & 68 & 51 & 120 & 100 \\
\hline Rato 3 & 66 & 54 & 140 & 110 \\
\hline Rato 4 & $\mathrm{XXX}$ & $\mathrm{XXX}$ & $\mathrm{XXX}$ & $\mathrm{XXX}$ \\
\hline Rato 5 & 59 & 47 & 150 & 80 \\
\hline Rato 6 & 75 & 50 & 180 & 100 \\
\hline
\end{tabular}

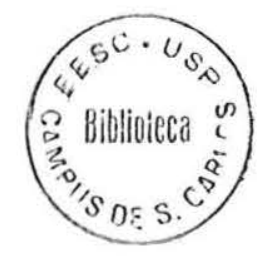




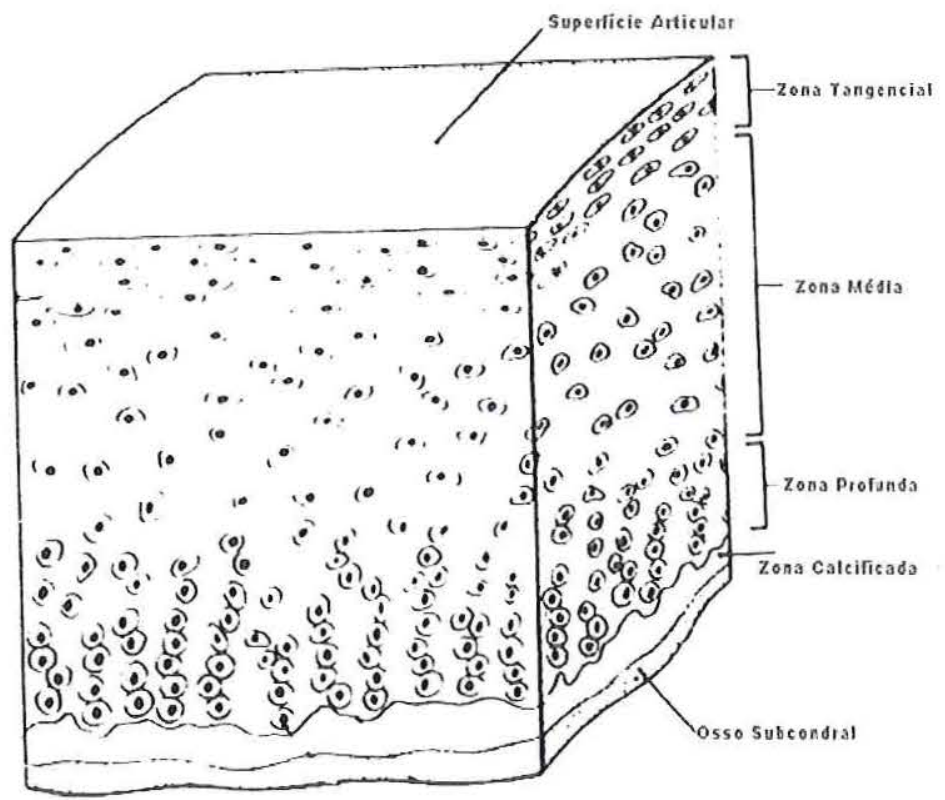

A

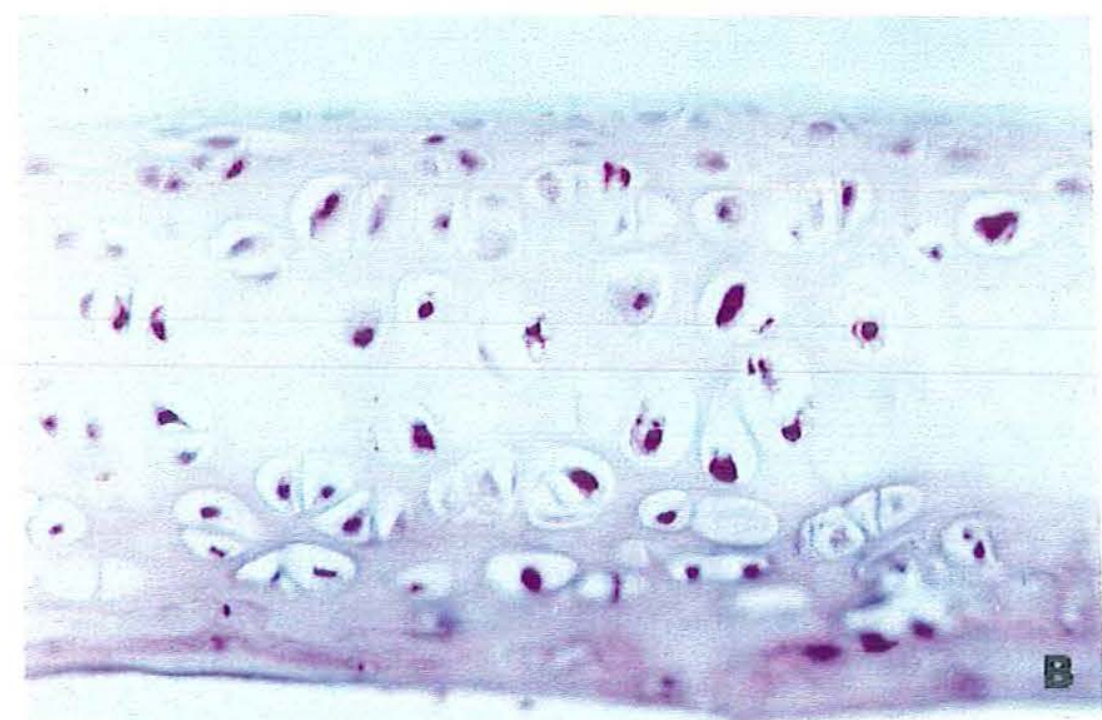

Figura 7 - Distribuição dos condrócitos nas zonas superficial, média e profunda da cartilagem articular. (A) - Representação diagramática da cartilagem articular. (B) - Aspecto da distribuição dos condrócitos nas zonas da cartilagem articular. 

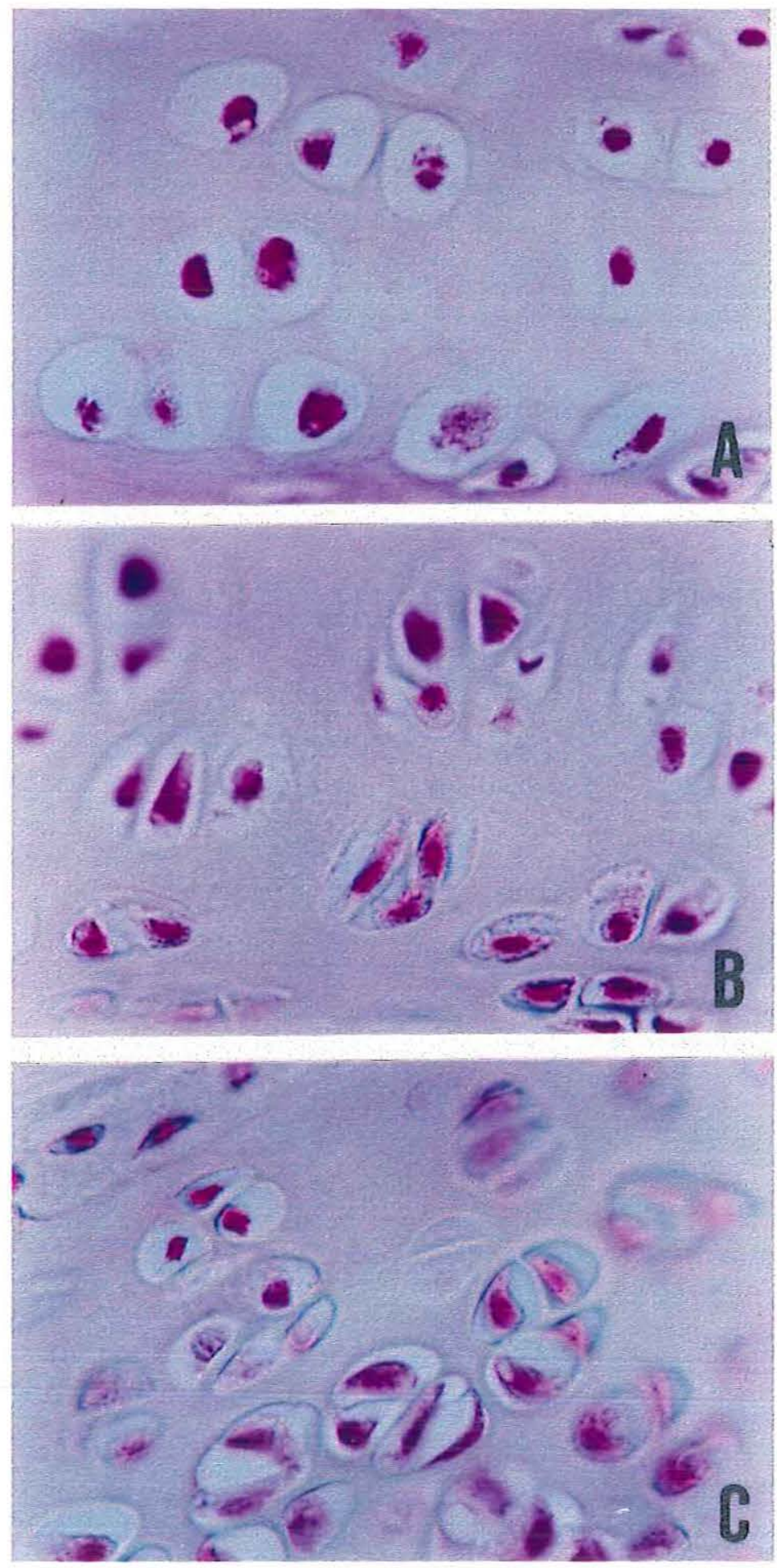

Figura 8 - Contagem de células (Hematoxylin \& eosin, X 450): (A) Aspecto histológico do côndilo do rato controle (normal); (B) Aspecto histológico do côndilo do rato submetido a exercícios com 40 ciclos em grande amplitude; (C) Aspecto histológico do côndilo do rato submetido a exercícios com 80 ciclos em grande amplitude. 

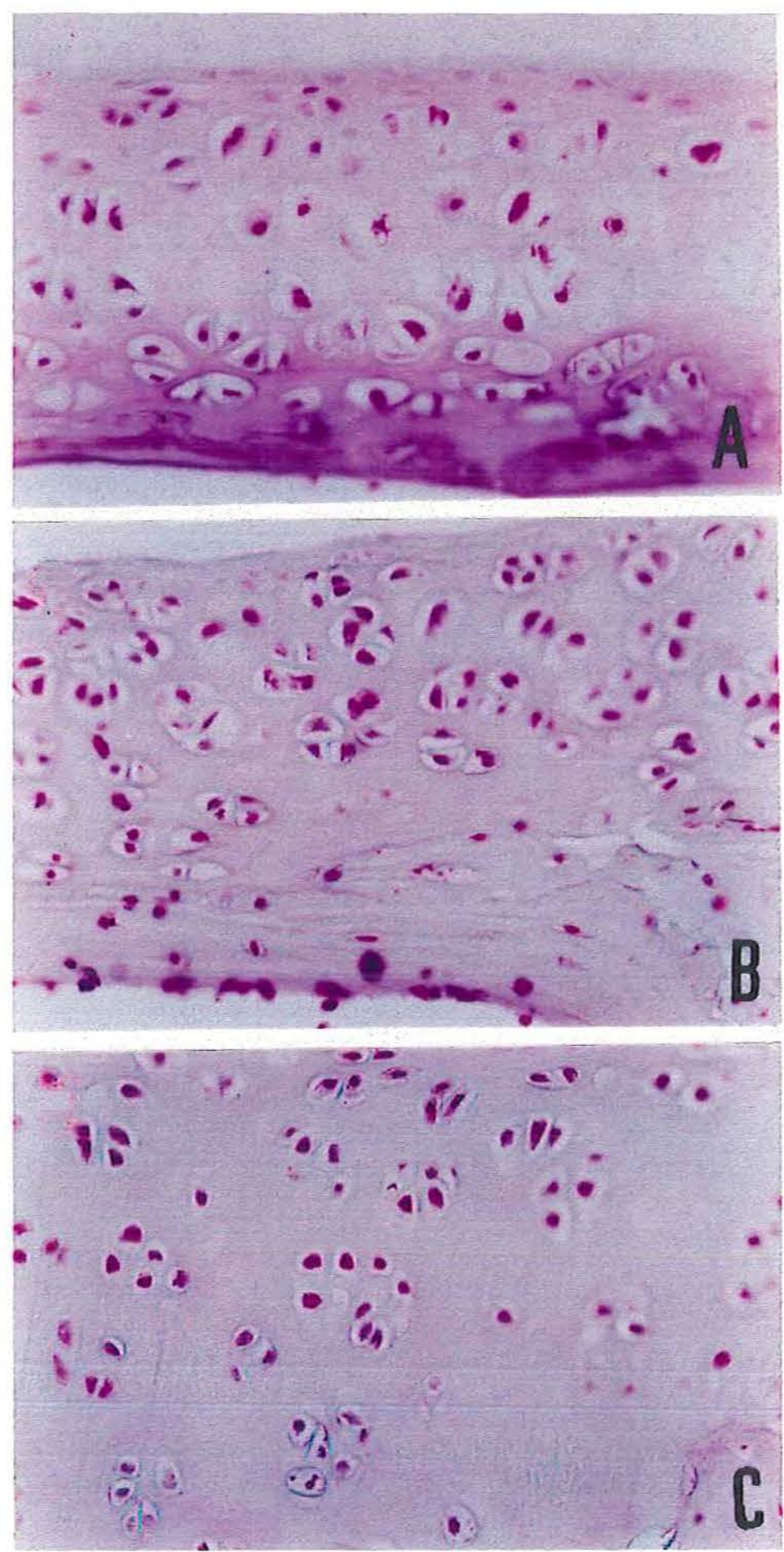

Fig. 9 - Espessura da cartilagem (hematoxylin \& eosin, X 100): (A) - Aspecto do condilo do rato controle; (B) Aspecto do condilo do rato submetido a exercícios com 40 ciclos em grande amplitude; (C) Aspecto do condilo do rato submetido a exercícios com 80 ciclos em grande amplitude. 


\section{3 - Análise Estatística}

\subsection{1 - Peso Inicial}

$\mathrm{O}$ quadro 5 mostra os valores individuais do peso dos animais estudados no início do experimento.

Quadro 5- Peso (gramas) inicial dos animais nos respectivos grupos

\begin{tabular}{|c|c|c|c|c|}
\hline & $\begin{array}{c}\text { Grupo 01 } \\
\text { 80ciclos/min. } \\
\text { Grande } \\
\text { amplitude }\end{array}$ & $\begin{array}{c}\text { Grupo 02 } \\
\text { 80 ciclos/min. } \\
\text { pequena } \\
\text { amplitude }\end{array}$ & $\begin{array}{c}\text { Grupo 03 } \\
\text { 40 ciclos/min. } \\
\text { grande } \\
\text { amplitude }\end{array}$ & $\begin{array}{c}\text { Grupo 04 } \\
\text { 40 ciclosmin. } \\
\text { Pequena } \\
\text { amplitude }\end{array}$ \\
\hline Rato 1 & 240 & 241 & 295 & 238 \\
\hline Rato 2 & 260 & 286 & 272 & 253 \\
\hline Rato 3 & 280 & 268 & 210 & 268 \\
\hline Rato 4 & 274 & 264 & 252 & 258 \\
\hline Rato 5 & 280 & 248 & 280 & 265 \\
\hline Rato 6 & $\mathrm{XXX}$ & 241 & 298 & 285 \\
\hline
\end{tabular}

A análise de variância do peso inicial dos animais submetidos a movimentos contínuos de flexo-extensão, não apresentou diferenças significantes entre os grupos (Valor de $\mathrm{F}=0.874$ ) como pode ser observado na tabela 1 e gráfico 5 . 
Tabela 1 - Valores médios do peso inicial dos animais dos grupos experimentais.

\begin{tabular}{ccc}
\hline \hline GRUPOS & $\mathrm{N}^{\mathrm{a}}$ & PESO INICIAL $^{\mathrm{b}}$ \\
\hline GRUPO 1 & 05 & $257,3 \pm 11,3$ \\
GRUPO 2 & 06 & $258,0 \pm 7,3$ \\
GRUPO 3 & 06 & $266,8 \pm 13,0$ \\
GRUPO 4 & 06 & $261,1 \pm 6,4$ \\
\hline \hline
\end{tabular}

${ }^{\bar{a}}$ Número de animais

${ }^{\mathrm{b}}$ Peso dos animais em gramas.

Gráfico 1 - Peso inicial dos animais (gr) submetidos a movimento de flexoextensão contínua do joelho.

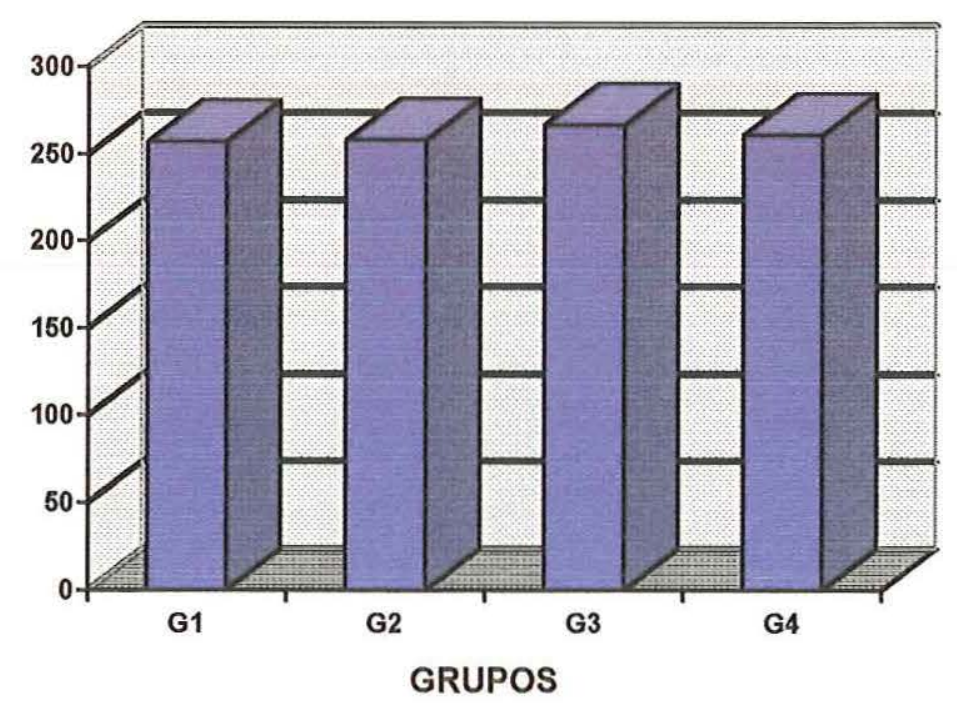

口peso inicial 


\subsection{2 - Peso final}

O peso final individual dos animais submetidos a movimentos de flexo-extensão contínua do joelho pode ser visualizado no quadro 6 .

Quadro 6- Peso final, em gramas, dos animais nos respectivos grupos experimentais.

\begin{tabular}{|c|c|c|c|c|}
\hline & $\begin{array}{c}\text { Grupo 01 } \\
\text { 80 ciclos/min. } \\
\text { grande } \\
\text { amplitude }\end{array}$ & $\begin{array}{c}\text { Grupo 02 } \\
\mathbf{8 0} \text { ciclos/min. } \\
\text { pequena } \\
\text { amplitude }\end{array}$ & $\begin{array}{c}\text { Grupo 03 } \\
\mathbf{4 0} \text { ciclos/min. } \\
\text { grande } \\
\text { amplitude }\end{array}$ & $\begin{array}{c}\text { Grupo 04 } \\
\text { 40 ciclos/min. } \\
\text { Pequena } \\
\text { amplitude }\end{array}$ \\
\hline Rato 1 & 251 & 280 & 308 & 265 \\
\hline Rato 2 & 270 & 338 & 325 & 330 \\
\hline Rato 3 & 315 & 278 & 232 & 307 \\
\hline Rato 4 & 285 & 301 & 271 & 308 \\
\hline Rato 5 & 306 & 280 & 295 & 320 \\
\hline Rato 6 & XXX & 290 & 360 & 310 \\
\hline
\end{tabular}

A tabela 2 e o gráfico 2 mostram os valores médios do peso final dos animais submetidos a movimentos de flexo-extensão contínua. A análise de variância do peso final desses animais, não apresentou diferenças significantes entre os grupos (Valor de $\mathrm{F}=0.462$ ). 
Tabela 2 - Valores médios de peso final dos animais submetidos a exercícios de flexo-extensão contínua.

\begin{tabular}{ccc}
\hline \hline GRUPOS & $\mathrm{N}^{\mathrm{a}}$ & PESO FINAL $^{\mathrm{b}}$ \\
\hline GRUPO 1 & 5 & $276,5 \pm 13,0$ \\
GRUPO 2 & 6 & $294,5 \pm 9,3$ \\
GRUPO 3 & 6 & $298,5 \pm 18,0$ \\
GRUPO 4 & 6 & $306,7 \pm 9,0$ \\
\hline \hline
\end{tabular}

${ }^{a}$ Número de animais

${ }^{\mathrm{b}}$ Peso dos animais em gramas

Gráfico 2 - Peso final dos animais (gr) submetidos a movimentos de flexoextensão contínua do joelho.

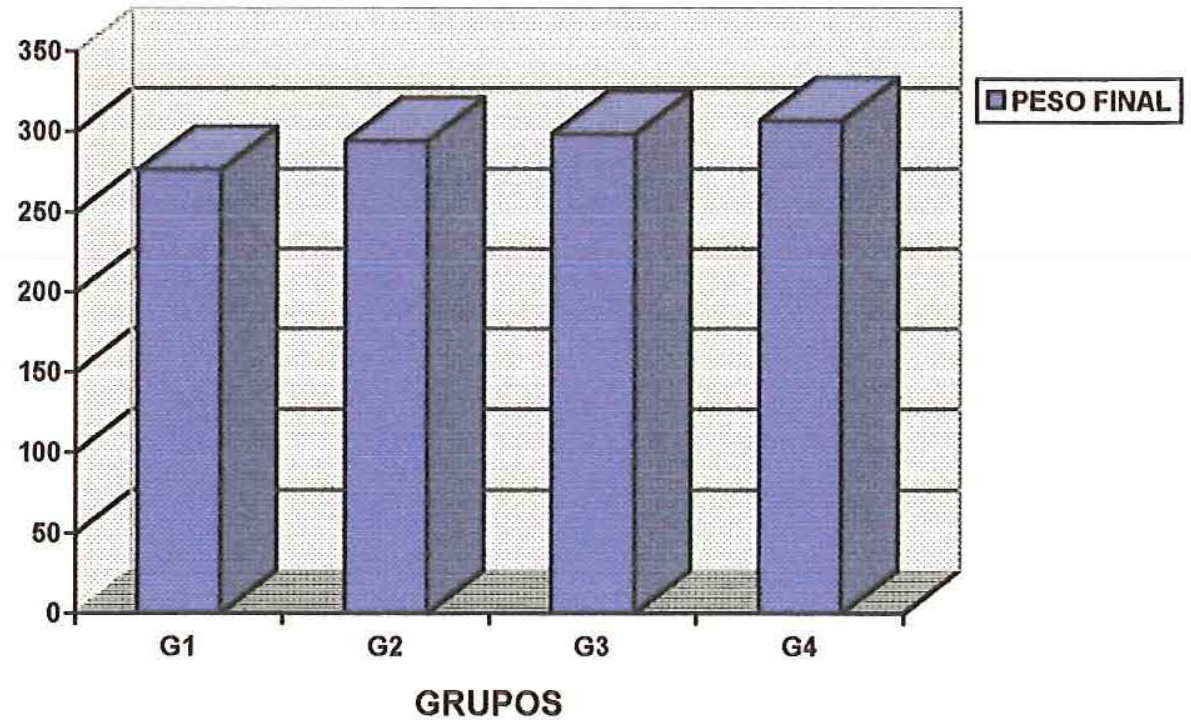




\subsection{3 - Contagem de Células}

As tabelas 3 e 4 demonstram os valores médios obtidos através da contagem de células da cartilagem articular de joelhos controle submetidos a exercícios de flexo-extensão contínua. A análise permite concluir que existem diferenças estatisticamente significantes na contagem de células entre os joelhos controle e estressados, submetidos a exercícios de flexo-extensão contínua com velocidade de 80 ciclos/min. e grande amplitude (grupo 01), velocidade 80 ciclos/min. e pequena amplitude (grupo 02), velocidade de 40 ciclos/min. e grande amplitude (grupo 03) e velocidade de 40 ciclos $/ \mathrm{min}$. e pequena amplitude (grupo 4), também visualizados nos gráficos 3, 4, 5, 6 e 7 .

A análise de variância entre os grupos submetidos a exercícios contínuos de flexo-extensão demostrou que o grupo submetido a exercícios com velocidade de 80 ciclos/min. e grande amplitude (grupo 1) foi estatisticamente diferente do grupos exercitados a velocidade de 40 ciclos $/ \mathrm{min}$. e grande amplitude (grupo 3) e a velocidade de $40 \mathrm{ciclos} / \mathrm{min}$. e pequena amplitude (grupo 4) (Teste de Tukey, $\mathrm{p}<0,05$ ). $\mathrm{O}$ grupo exercitado à velocidade de 80 ciclos/min. e pequena amplitude (grupo 2) foi estatisticamente diferente do grupo exercitado à velocidade de 40 ciclos $/ \mathrm{min}$. e pequena amplitude. (Teste de Tukey, $\mathrm{p}<0,05$ ). Nos outros grupos não foram observadas alterações estatisticamente significantes. Nos joelhos controle não foram observadas diferenças estatisticamente significantes, (tabelas 3 e 4). 
Tabela 3 - Valores de contagem de células da cartilagem de joelhos de ratos submetidos a movimentos de flexo-extensão contínua com 80 ciclos/min. e em grande e pequena amplitude.

\begin{tabular}{ccc}
\hline \hline Grupos & $\begin{array}{c}\text { 80 Ciclos/min. }+ \\
\text { Grande Amplitude }^{\text {a }}\end{array}$ & $\begin{array}{c}\text { 80 Ciclos/min. + } \\
\text { Pequena Amplitude }\end{array}$ \\
\hline Controle & $65,6 \pm 5,6$ & $60,0 \pm 3,3$ \\
Experimental & $(05)^{\mathrm{b}}$ & $(06)^{\mathrm{b}}$ \\
& $131,6 \pm 8,1^{*_{\mathrm{c}}}$ & $105,0 \pm 6,8^{*_{\mathrm{d}}}$ \\
& $(05)^{\mathrm{b}}$ & $(06)^{\mathrm{b}}$ \\
\hline \hline
\end{tabular}

${ }^{3}$ Valores médios em milímetros acompanhados dos respectivos erros padrões das médias.

'Os números colocados entre parênteses, imediatamente abaixo de cada valor médio, representam o número de experimentos daquele grupo.

'Diferença estatisticamente significante em relą̧ão ao grupo submetidos a exercícios de flexoextensão contínua com 40 ciclos $/ \mathrm{min}$. em grande e pequena amplitude $(p<0,05$; teste de Tukey), conforme visualização na tabela 4 .

'Diferença estatisticamente significante em relação ao grupo submetido a flexo-extensão contínua com 40 ciclos/min. e pequena amplitude ( $<<0,05$; teste de Tukey), conforme visualização na tabela 4 .

*Diferença estatisticamente significante em relação ao respectivo grupo controle $(\mathrm{p}<0,05$; teste de Student).

O gráfico 3 mostra os valores médios de contagem de células de joelhos controles e submetidos a movimentos de flexo-extensão contínua com velocidade de 80 ciclos/min. e grande amplitude. Os valores médios foram respectivamente de $65,6 \pm 5,6$ e 131,6 $\pm 8,1$ apresentando diferenças estatisticamente significante. No gráfico 4 , podemos visualizar estes valores em joelhos controles e submetidos a movimentos com velocidade de $80 \mathrm{ciclos} / \mathrm{min}$. e pequena amplitude. Os valores obtidos apresentaram diferenças 
estatisticamente significantes, com valores médios de $60,0 \pm 3,3$ para o grupo controle e de $105,0 \pm 6,8$ para o grupo estressado.

Gráfico 3 - Valores de contagem de células da cartilagem de joelhos de ratos submetidos a movimentos de flexo-extensão contínua com 80 ciclos/min. e em grande amplitude.

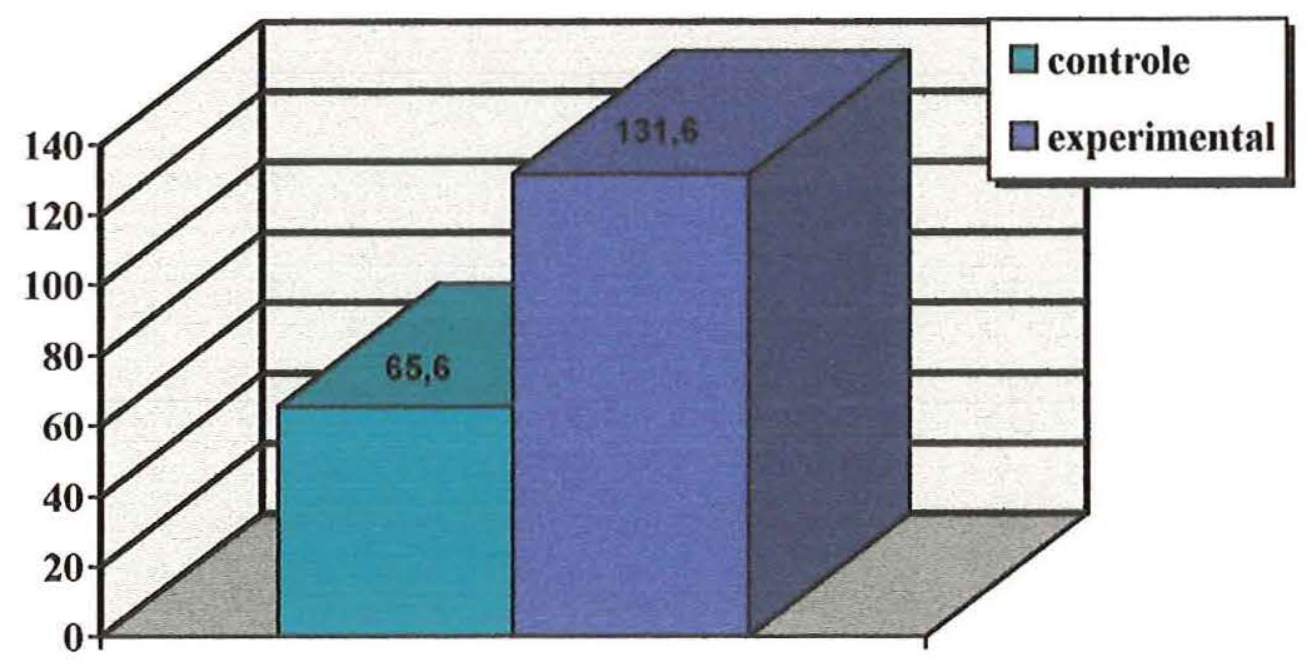

80 Ciclos + Grande Amplitude

Gráfico 4 - Valores de contagem de células da cartilagem de joelhos de ratos submetidos a movimentos de flexo-extensão contínua com $80 \mathrm{ciclos} / \mathrm{min}$. e em pequena amplitude.

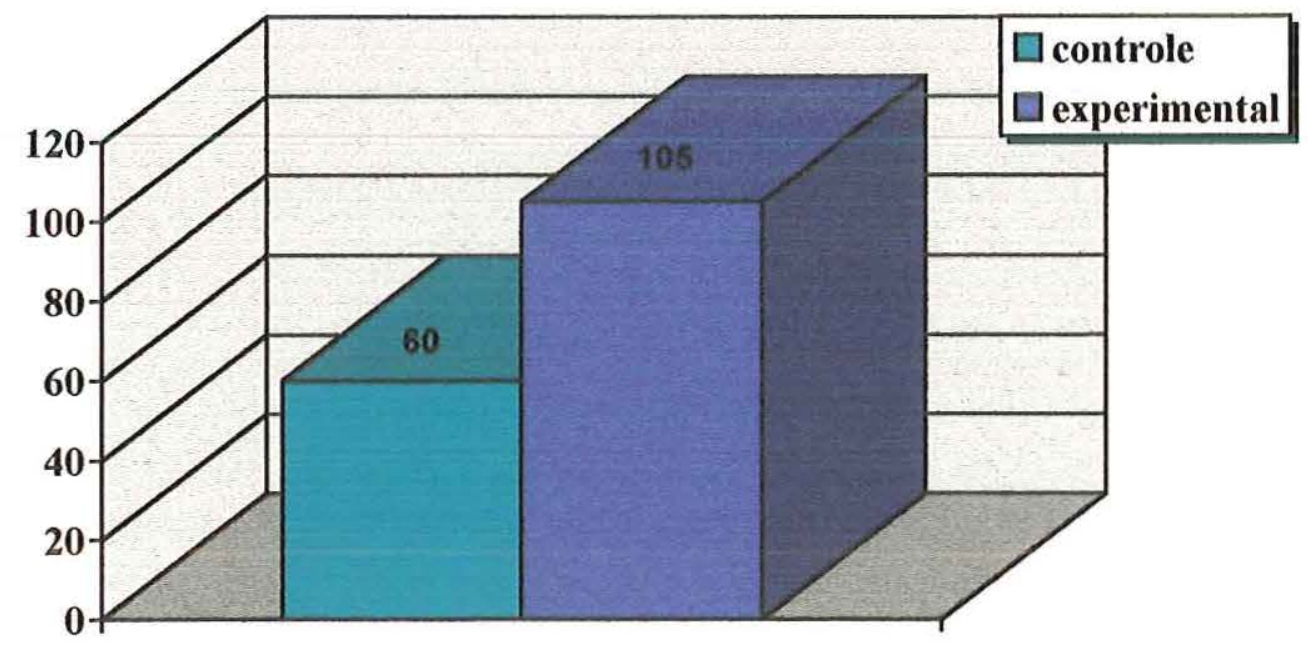

80 Ciclos + Pequena Amplitude 
Tabela 4 - Valores de contagem de células ${ }^{\mathrm{a}}$ da cartilagem articular de joelhos de ratos submetidos a movimentos de flexo-extensão contínua com 40 ciclos/min. , em grande e pequena amplitude.

\begin{tabular}{ccc}
\hline \hline Grupos & $\begin{array}{c}\mathbf{4 0} \text { ciclos/min. }+ \\
\text { Grande Amplitude }^{\text {a }}\end{array}$ & $\begin{array}{c}\mathbf{4 0} \text { Ciclos/min. }^{+} \\
\text {Pequena Amplitude }^{\text {a }}\end{array}$ \\
\hline Controle & $58,8 \pm 2,5$ & $51,2 \pm 1,3$ \\
Experimental & $(06)^{\mathrm{b}}$ & $(05)^{\mathrm{b}}$ \\
& $81,0 \pm 8,7^{*}$ & $66,0 \pm 2,7^{*}$ \\
& $(06)^{\mathrm{b}}$ & $(05)^{\mathrm{b}}$ \\
\hline \hline
\end{tabular}

${ }^{a}$ Valores médios em milímetros acompanhados dos respectivos erros padrões das médias.

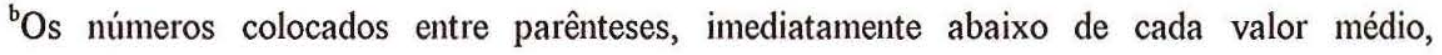
representam o número de experimentos daquele grupo.

*Diferença estatisticamente significante em relação ao respectivo grupo controle $(\mathrm{p}<0,05$; teste de Student).

Os valores médios de contagem de células de joelhos controles e submetidos a movimentos de flexo-extensão contínua, com velocidade de 40 ciclos/min. e grande amplitude, foram respectivamente $58,8 \pm 2,5$ e $81,0 \pm 8,7$ e podem ser visualizados no gráfico 5 . Estes valores apresentaram diferenças estatisticamente significantes.

No gráfico 6 estão demonstrados os valores médios dessa contagem nos joelhos de animais controles e estressados submetidos a movimentos de flexo-extensão contínua, com velocidade de 40 ciclos/min. e pequena amplitude. Estes valores apresentaram diferenças estatística e foram de $51,2 \pm 1,3$ para os joelhos controles e $66,0 \pm 2,7$ para os joelhos submetidos aos movimentos de flexo-extensão. 
Gráfico 5 - Valores de contagem de células ${ }^{a}$ da cartilagem articular de joelhos de ratos submetidos a movimentos de flexo-extensão contínua com 40 ciclos/min. , em grande amplitude.

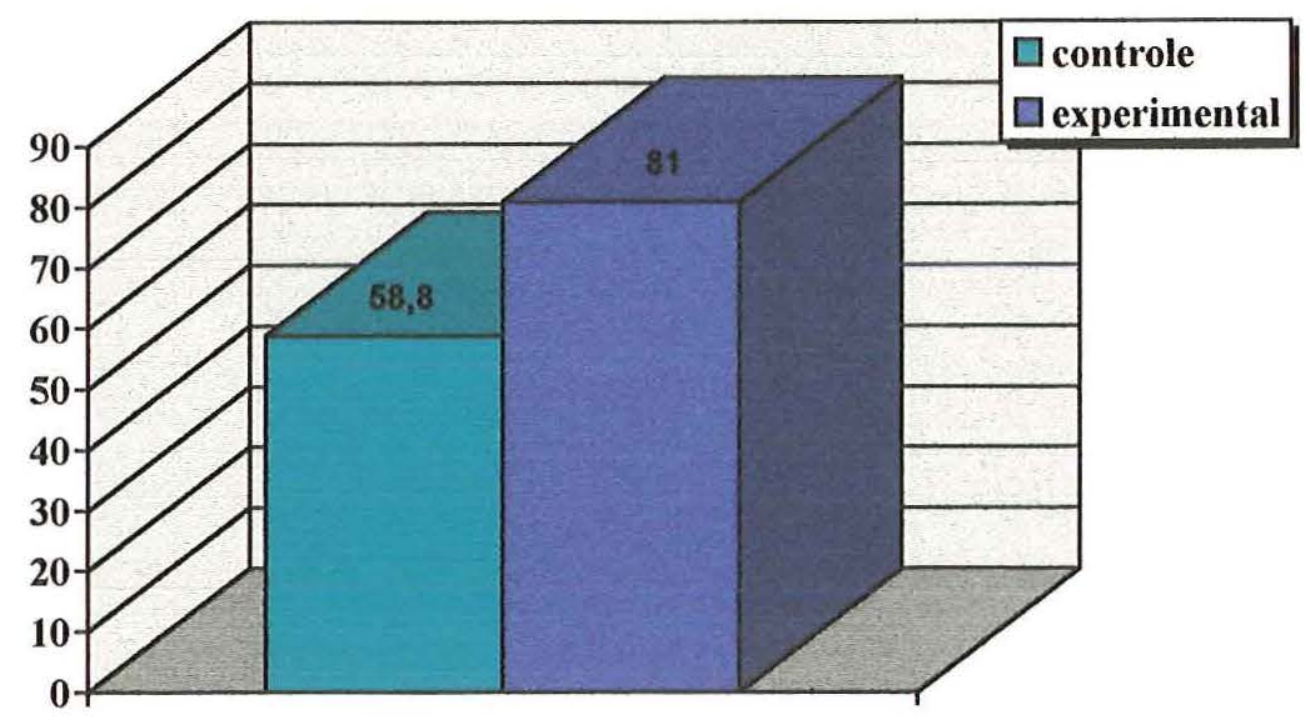

40 Ciclos + Grande Amplitude

Gráfico 6 - Valores de contagem de células ${ }^{\mathrm{a}}$ da cartilagem articular de joelhos de ratos submetidos a movimentos de flexo-extensão contínua com 40 ciclos/min., em pequena amplitude.

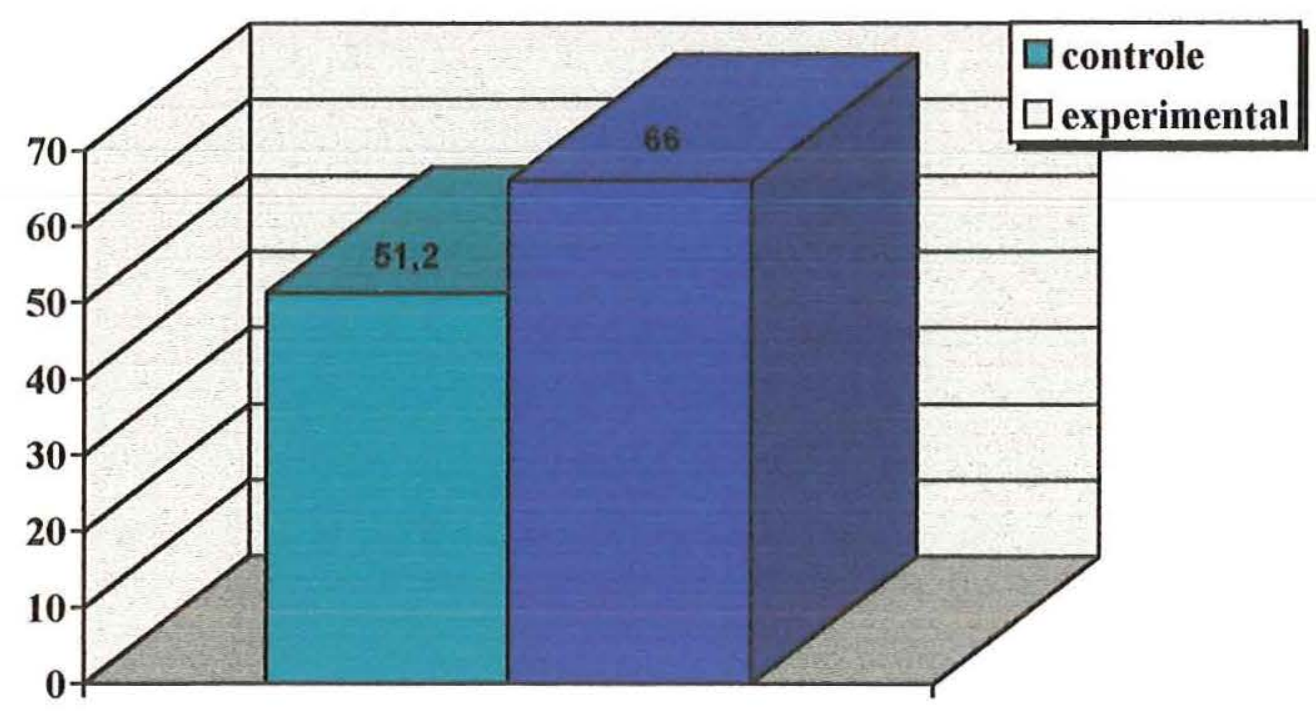

40 Ciclos + Pequena Amplitude 
Gráfico 7 - Relação entre grupo controle e experimental quanto a valores de contagem de células.

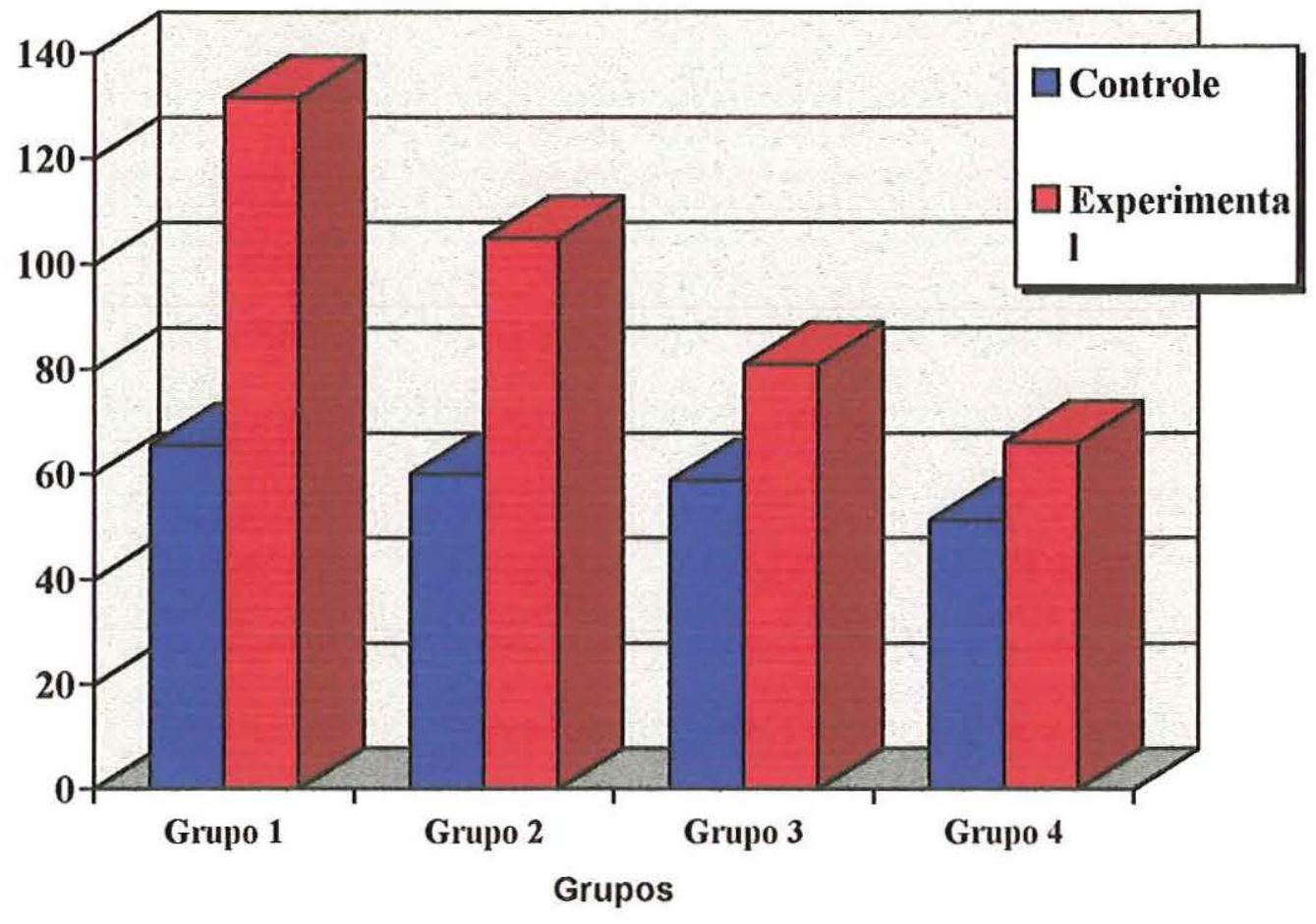




\subsection{4 - Espessura da Cartilagem Articular}

As tabelas 5 e 6 demonstram os valores obtidos através da mensuração (microns), da espessura da cartilagem articular de animais controle e submetidos a exercícios de flexo-extensão contínua. A análise permite concluir que existem diferenças estatisticamente significantes na medida de espessura entre os animais controle e exercitados, submetidos a exercícios de flexo-extensão contínua com velocidade de 80 ciclos/min. e grande amplitude (grupo 1), velocidade 80 ciclos/min. e pequena amplitude (grupo 2), velocidade de 40 ciclos/min. e grande amplitude (grupo 3 ) e velocidade de 40 ciclos $/ \mathrm{min}$. e pequena amplitude (grupo 4), também visualizados nos gráficos $8,9,10,11 \mathrm{e}$ 12 e figura 9-A; 9-B; e 9-C.

A análise de variância entre os grupos submetidos a exercícios de flexo-extensão contínua, demonstrou que o grupo submetido a exercícios com velocidade de 80 ciclos/min. e grande amplitude (grupo 1), foi estatisticamente diferente dos grupo exercitado à velocidade de 40 ciclos $/ \mathrm{min}$. e pequena amplitude (grupo 4) (Teste de Tukey, $\mathrm{p}<0,05$ ). $\mathrm{O}$ grupo que foi exercitado à velocidade de $80 \mathrm{ciclos} / \mathrm{min}$. e pequena amplitude (grupo 2), foi estatisticamente diferente do grupo que foi exercitado à velocidade de 40 ciclos/min. e pequena amplitude (grupo 4) (Teste de Tukey, $\mathrm{p}<0,05$ ). Nos outros grupos não foram observadas alterações estatisticamente significantes. No grupo de joelhos controle não observou-se diferenças estatisticamente significantes, como pode ser verificado nas tabelas 5 e 6 . 
Tabela 5 - Valores da espessura da cartilagem articular de joelhos de ratos submetidos a movimentos de flexo-extensão contínua com 80 ciclos/min., em grande e pequena amplitude.

\begin{tabular}{ccc}
\hline \hline Grupos & $\begin{array}{c}\mathbf{8 0} \text { ciclos/min. }+ \\
\text { Grande Amplitude }^{\mathrm{a}}\end{array}$ & $\begin{array}{c}\mathbf{8 0} \text { ciclos/min. }+ \\
\text { Pequena Amplitude }^{\mathrm{a}}\end{array}$ \\
\hline Controle & $100 \pm 5$ & $100 \pm 7$ \\
Experimental & $(05)^{\mathrm{b}}$ & $(06)^{\mathrm{b}}$ \\
& $210 \pm 7^{{ }^{* \mathrm{c}}}$ & $200 \pm 6^{{ }^{* \mathrm{c}}}$ \\
& $(05)^{\mathrm{b}}$ & $(06)^{\mathrm{b}}$ \\
\hline \hline
\end{tabular}

${ }^{a}$ Valores médios em microns $(\mu \mathrm{m})$ acompanhados dos respectivos erros padrões das médias.

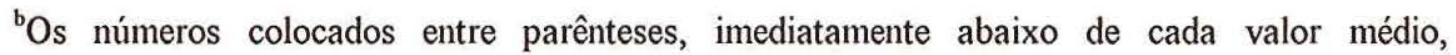
representam o número de experimentos daquele grupo.

'Diferença estatisticamente significante em relação ao grupo submetidos a exercícios de flexoextensão contínua com 40 ciclos/min. e pequena amplitude $(\mathrm{p}<0,05$; teste de Tukey) visualizado na tabela 6 .

*Diferença estatisticamente significante em relação ao respectivo grupo controle $(p<0,05$; teste $t$ de Student).

O gráfico 8 demonstra os valores médios de espessura da cartilagem articular de joelhos controles e submetidos a movimentos de flexoextensão contínua do joelho com velocidade de 80 ciclos/min. e grande amplitude. Estes valores foram respectivamente $100 \pm 5$ e $210 \pm 7$ e, apresentaram diferenças estatisticamente significantes entre si.

No gráfico 9 podemos visualizar estes valores para os joelhos controles e submetidos a movimentos com velocidade de 80 ciclos $/ \mathrm{min}$. e pequena amplitude, que também apresentaram diferenças estatística e foram, respectivamente, $100 \pm 7$ e $200 \pm 6$. 
Gráfico 8 - Valores da espessura da cartilagem articular $(\mu \mathrm{m})$ de joelho de ratos submetidos a movimentos de flexo-extensão contínua com 80 ciclos/min., em grande amplitude.

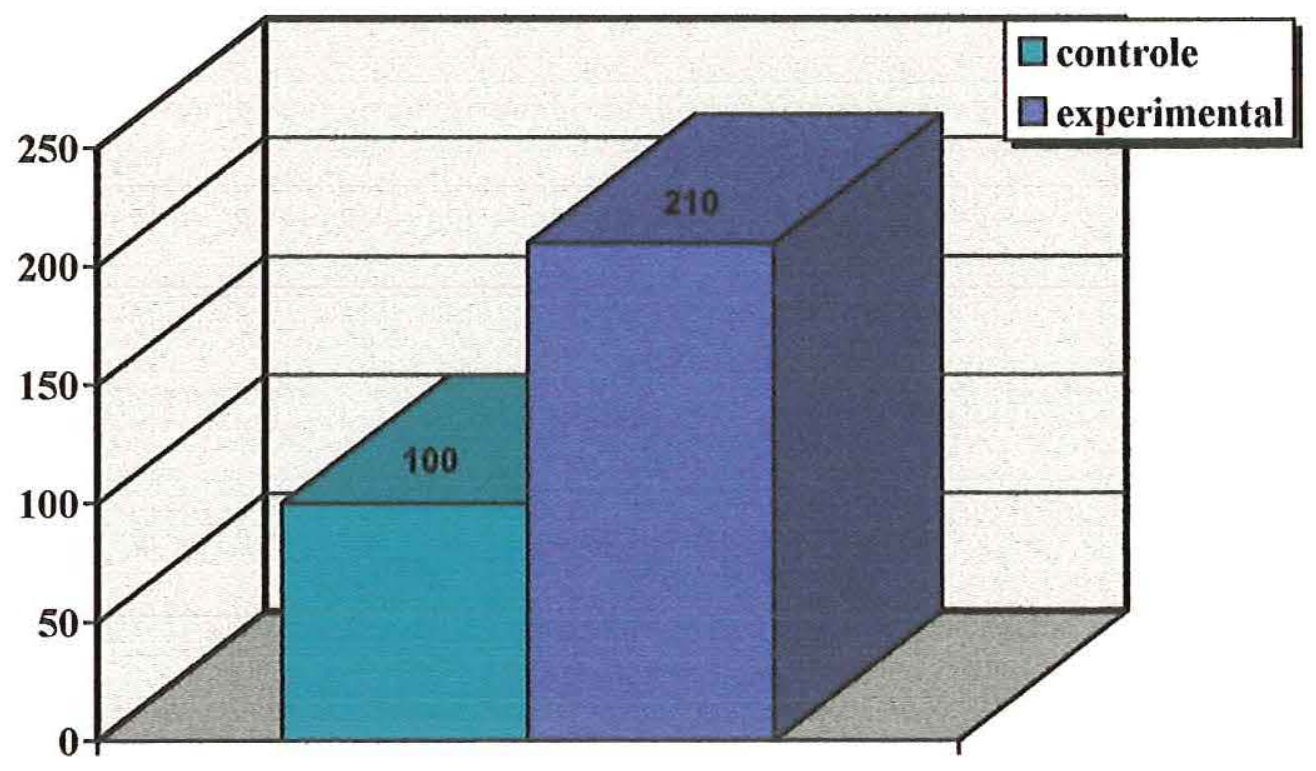

80 Ciclos + Grande Amplitude

Gráfico 9 - Valores da espessura da cartilagem articular $(\mu \mathrm{m})$ de joelhos de ratos submetidos a movimentos de flexo-extensão contínua com 80 ciclos/min., em pequena amplitude.

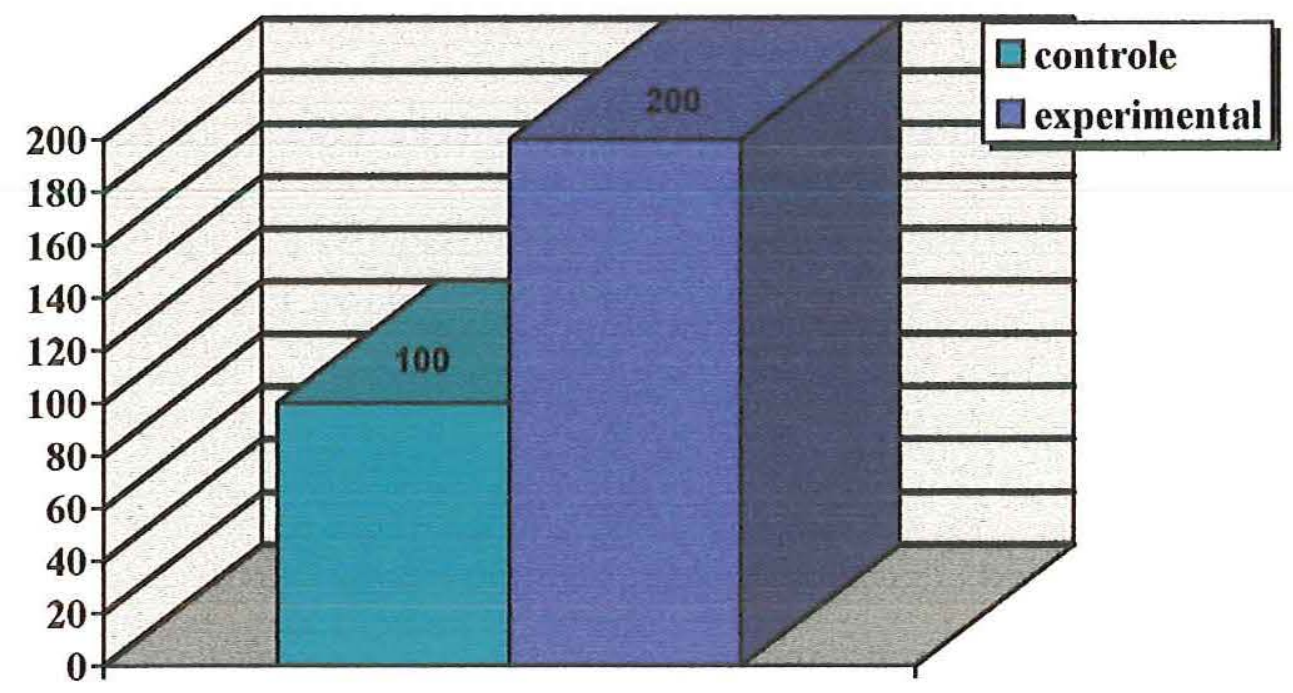

80 Ciclos + Pequena Amplitude 
Tabela 6 - Valores da espessura da cartilagem articular de joelho de ratos submetidos a movimentos de flexo-extensão contínua com 40 ciclos/min., em grande e pequena amplitude.

\begin{tabular}{|c|c|c|}
\hline Grupos & $\begin{array}{c}40 \text { ciclos/min. + } \\
\text { Grande Amplitude a }\end{array}$ & $\begin{array}{c}40 \text { ciclos } / \mathrm{min} .+ \\
\text { Pequena Amplitude }^{\text {a }}\end{array}$ \\
\hline Controle & $\begin{array}{c}100 \pm 4 \\
(06)^{b}\end{array}$ & $\begin{array}{c}100 \pm 7 \\
(05)^{b}\end{array}$ \\
\hline Experimental & $\begin{array}{c}180 \pm 8^{* \mathrm{c}} \\
(06)^{\mathrm{b}}\end{array}$ & $\begin{array}{c}150 \pm 10^{*} \\
(05)^{b}\end{array}$ \\
\hline \multicolumn{3}{|c|}{$\begin{array}{l}{ }^{\mathrm{a}} \text { Valores médios em microns }(\mu \mathrm{m}) \text { acompanhados dos respectivos erros padrões das médias. }{ }^{\mathrm{b}} \mathrm{O} \\
\text { números colocados entre parênteses, imediatamente abaixo de cada valor médio, representam c } \\
\text { número de experimentos daquele grupo. 'Diferença estatisticamente significante em relação ac } \\
\text { grupo submetidos a exercícios de flexo-extensão contínua com } 40 \text { ciclos/min. e pequena } \\
\text { amplitude ( }<<0,05 \text {; teste de Tukey). *Diferença estatisticamente significante em relação ac } \\
\text { respectivo grupo controle }(p<0,05 \text {; teste } t \text { de Student). }\end{array}$} \\
\hline
\end{tabular}

No gráfico 10 podemos visualizar os valores médios de espessura da cartilagem articular de joelhos controles e submetidos a flexo-extensão contínua, com velocidade de 40 ciclos/min. e grande amplitude. Observamos que os valores médios foram de $100 \pm 4$ para o grupo controle e de $180 \pm 8$ para o grupo estressado, que são valores que apresentam diferenças estatística.

Da mesma forma, os joelhos controles e submetidos a movimentos com velocidade de 40 ciclos $/ \mathrm{min}$. e pequena amplitude, também apresentaram diferenças estatisticamente significantes, com valores médios de $100 \pm 7$ e 150 \pm 10 , respectivamente. Estes dados podem ser visualizados no gráfico 11 . 
Gráfico 10 - Valores da espessura da cartilagem articular $(\mu \mathrm{m})$ de joelhos de ratos submetidos a movimentos de flexo-extensão contínua com 40 ciclos/min., em grande amplitude.

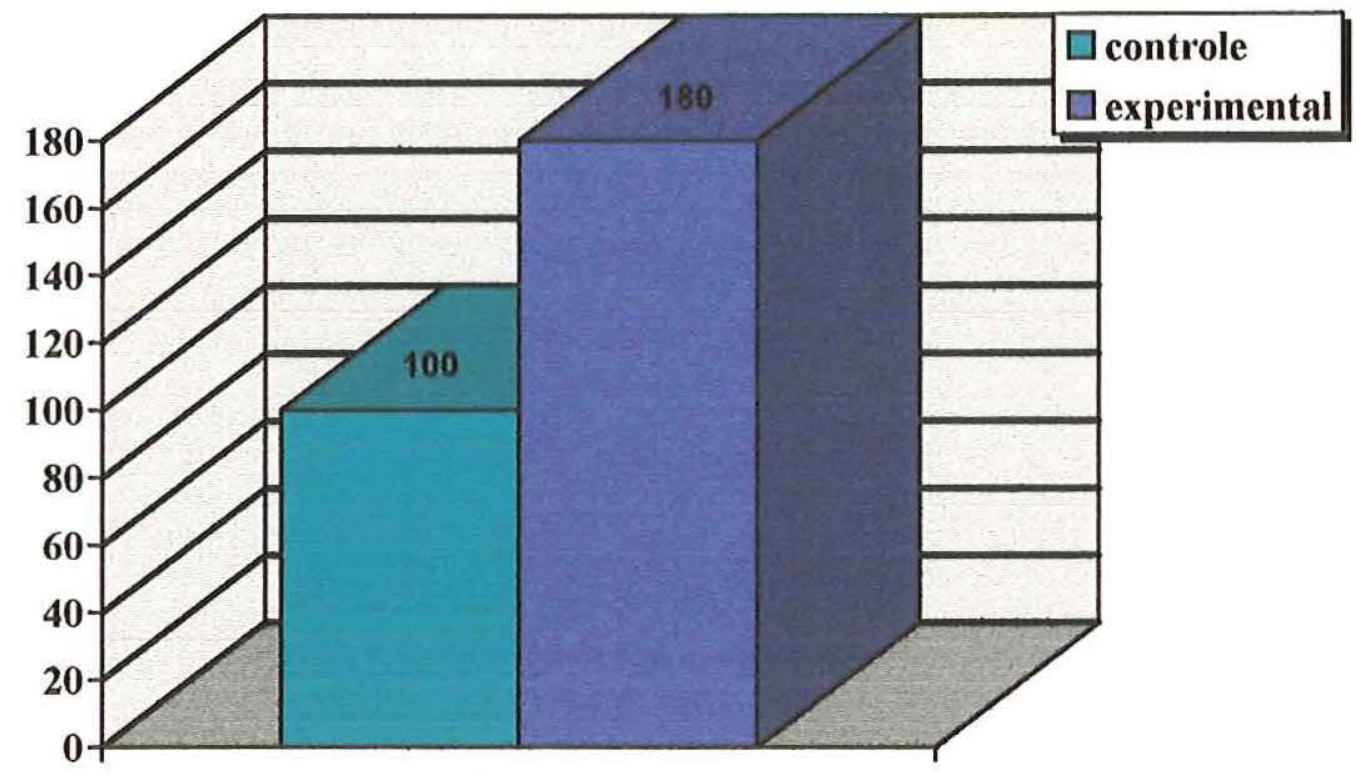

40 Ciclos + Grande Amplitude

Gráfico 11- Valores da espessura da cartilagem articular $(\mu \mathrm{m})$ de joelho de ratos submetidos a movimentos de flexo-extensão contínua com 40 ciclos/min. , em pequena amplitude.

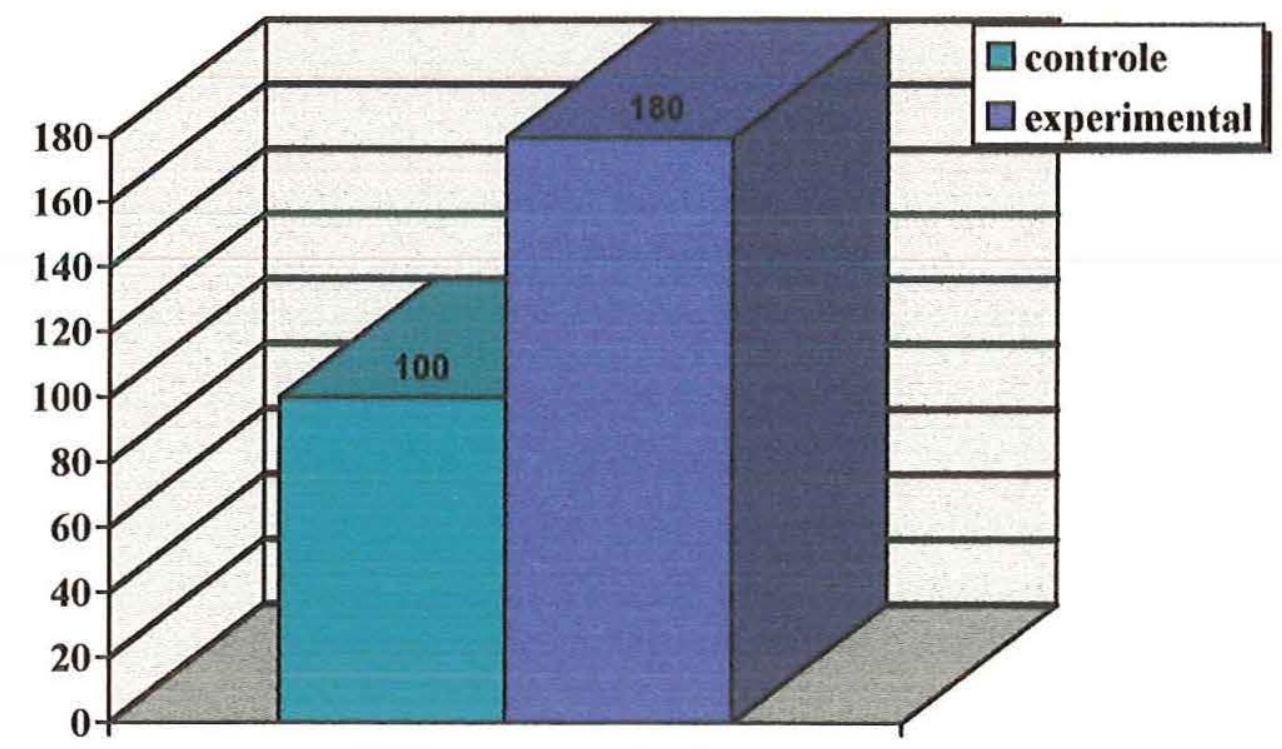

40 ciclos + Pequena Amplitude 
Gráfico 12 - Relação entre grupo controle e experimental quanto a valores de espessura $(\mu \mathrm{m})$.

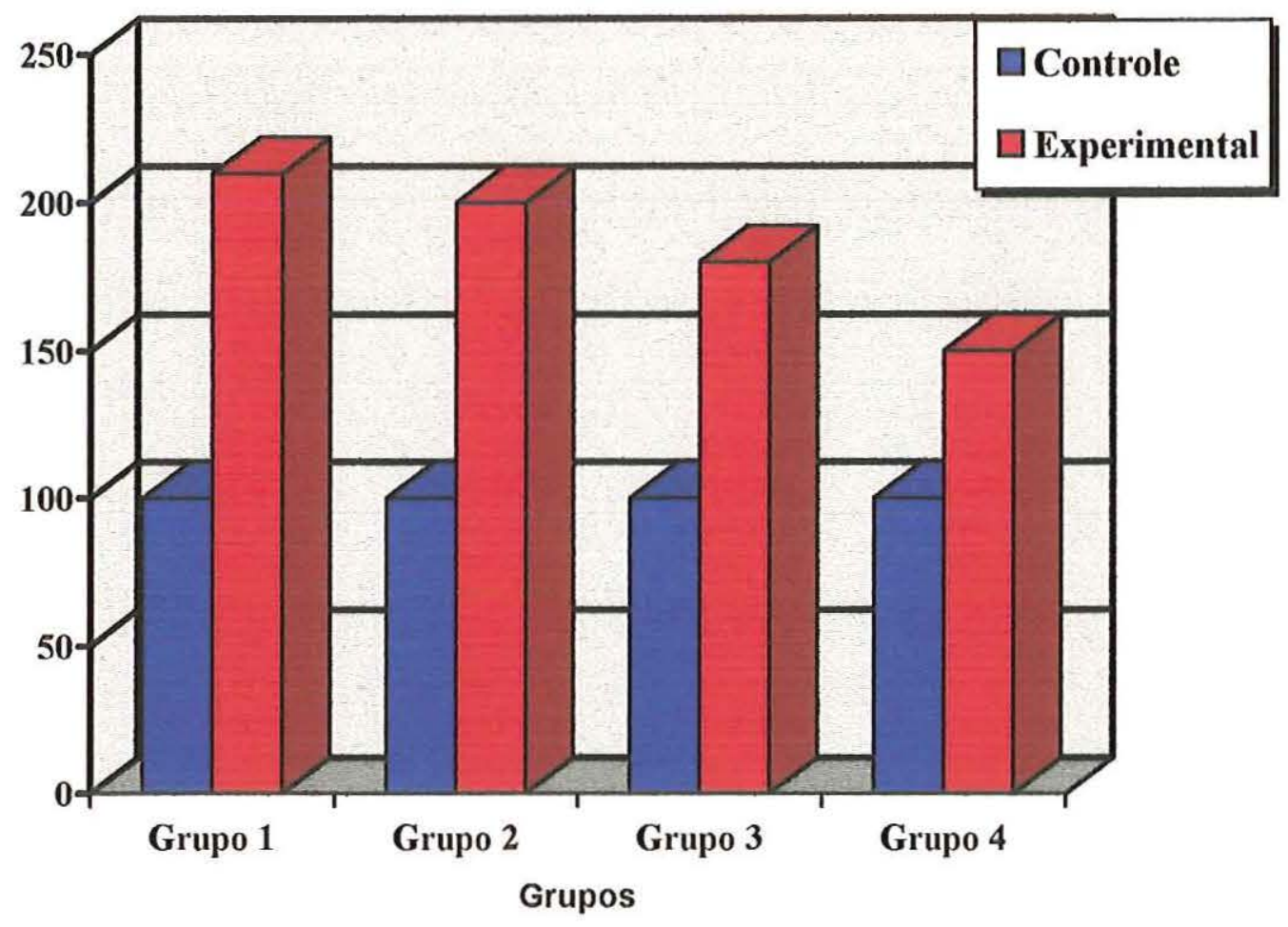


6. DISCUSSÃO

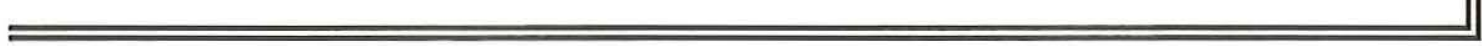




\section{DISCUSSÃO}

O estresse pode ser considerado um esforço realizado pelo organismo para adaptar-se ou reagir a agentes que ameaçam a integridade ou o equilíbrio orgânico (DUARTE, 1986). Frente a agentes estressores, o organismo desencadeia uma série de modificações metabólicas, fisiológicas e comportamentais que providenciam recursos para antecipar e reagir rapidamente contra a ameaça, preservando a homeostase e garantindo a sobrevivência.

Estas respostas do organismo estão intimamente relacionadas com o eixo hipotálamo/hipófise/adrenal e foi denominada por SELYE (1936), inicialmente, de Síndrome Geral de Adaptação e, posteriormente estresse.

$\mathrm{O}$ estresse representa a resposta do organismo, enquanto que o seu agente causador é definido como estímulo ou agente estressante ou estressor (PICKERING, 1981), os quais podem ser de várias naturezas, variando desde aspectos psicológicos até agentes químicos, físicos e/ou biológicos (DUARTE, 1986 ; GRIFFIN, 1989; CHROUSOS \& GOLD, 1992; FRANKS, 1994).

As respostas do organismo, frente a agentes estressantes podem produzir várias alterações anatomofisiológicas (CATERSON, 1978; KIVIRANTA et al, 1988; KEMPSON, 1991; YAN \& KERONG, 1995; VANDERLEI et al., 1996; ZANESCO et al., 1997).

Dentre essas alterações tem sido observadas modificações na cartilagem articular de animais, submetidos a estresse por imobilização (SMITH el al., 1992 ; YAN \& KERONG, 1995), procedimentos cirúrgicos 
como, por exemplo, modelos de osteotomias com finalidade de mudança do ângulo da articulação (LOVÁSZ et al., 1995), instabilidade ligamentar com a lesão do ligamento cruzado anterior (MCDEVITT, GILBERTSON e MUIR,1977; MANICOURT \& PITA, 1988), além de estresse mecânico como movimentos acrescidos de carga (NEWTON et al., 1997).

Neste trabalho foi utilizado um modelo de estresse mecânico que permitiu condições de verificar-se os efeitos de movimentos contínuos passivos sobre a cartilagem articular do joelho de ratos, onde a velocidade e a variação da amplitude de movimento puderam ser controladas rigorosamente, permitindo desta forma, estudar-se o processo de desgaste da cartilagem articular submetida a uso excessivo.

O modelo de estresse utilizado foi descrito por SILVA, PIVA, FONSECA (1978) e baseia-se no princípio biela-manivela, descrito anteriormente. Esse modelo apresenta a vantagem de não necessitar de exploração cirúrgica, não produzindo lesão da cartilagem articular pela realização desses procedimentos, portanto, as lesões observadas são atribuídas exclusivamente ao procedimento experimental realizado.

Para a realização deste experimento, os animais foram divididos em quatro grupos. Os grupos 1 e 2 realizaram movimentos com velocidade de 80 ciclos por minuto em grande e pequena amplitude, respectivamente, enquanto que os grupos 3 e 4 realizaram movimentos com velocidade de 40 ciclos por minuto em grande e pequena amplitude.

A aplicação destes modelos de estresse com intensidades variáveis não produziu alterações no peso corporal dos animais, como observado nas tabelas 1 e 2 . 
A análise histológica da cartilagem articular dos animais, submetidos a movimentos de flexo-extensão contínua do joelho, permitiu observar aumento de número de células em toda a área da cartilagem articular, que foi estatisticamente significante, em relação ao seu respectivo controle (Tabelas 3 e 4 ).

Aumento de tamanho e número de células da cartilagem articular em joelhos de cobaias, após realização de corrida durante três meses, com intensidade de $1 \mathrm{Km}$ por dia, foi observado por SAAF (1950).

SILVA, PIVA, FONSECA (1978), utilizando uma máquina de exercícios de flexo-extensão, também observaram aumento do número de células em joelhos de ratos, após 5 dias de exercícios com freqüências de 80 , 60 e 30 ciclos por minuto, sendo acompanhado de uma redução na concentração de proteoglicanas da matriz da cartilagem articular devido ao processo degenerativo da mesma, induzida pela aplicação deste tipo de estresse.

Os mecanismos responsáveis pelo aumento do número de células da cartilagem articular, induzida por estresse, ainda permanecem obscuros, entretanto, pode-se levantar algumas hipóteses para justificar esse aumento.

As alterações na concentração de proteoglicanas na matriz da cartilagem articular parecem estar diretamente relacionadas ao aumento do número de células encontrado no experimento.

As proteoglicanas são componentes da matriz extracelular, compostos de várias concentrações de glicosaminoglicanas, sulfatos 4 e 6 de Condroitina e Sulfato de Keratan, ligados a um núcleo de proteínas e agregados a moléculas de ácido hialurônico, formando um agregado de alto peso molecular capaz de unir grandes quantidades de água e ocupar um grande 
volume espacial, que está relacionado à propriedade de resistência compressiva quando da aplicação de carga sobre a cartilagem articular.

Como foi relatado anteriormente, SILVA, PIVA, FONSECA (1978), observaram que a aplicação de estresse sobre a cartilagem articular produz alterações degenerativas que levam a uma redução na concentração de proteoglicanas. Isso pode induzir a um aumento compensatório do número de células da cartilagem articular para elevar a concentração de proteoglicanas e aumentar a resistência compressiva da cartilagem, minimizando os efeitos da degeneração.

Portanto, o aumento no número de células da cartilagem articular, encontradas neste experimento com os animais submetidos a movimentos de flexo-extensão contínua, podem estar relacionado a aumento na concentração de proteoglicanas, visando minimizar os efeitos desencadeados pela aplicação de estresse.

Além disso, não se pode deixar de relatar que as células, responsáveis pela produção de proteoglicanas, podem desencadear mecanismos que promovem o aumento da síntese destas substâncias.

KIVIRANTA et al. (1987), observaram que a imobilização da pata traseira de cães, e conseqüente sobrecarga do membro oposto, produziu aumento de carga sobre a cartilagem articular que promoveu elevação da concentração de proteoglicanas.

LOVÁSZ et al. (1995), observaram que a indução de angulação do compartimento medial do joelho provocada por osteotomia, realizada para aumentar o atrito sobre a cartilagem articular, também produziu acréscimo do número de células. 
BUCKWALTER (1995), relatou que o aumento de movimento, consequentemente um aumento da carga de peso na superfície articular, pode ser um fator mecânico que estimula a síntese de proteoglicanas pelos condrócitos, no intuito de promover uma maior resistência compressiva.

Os procedimentos metodológicos utilizados neste experimento não permitiram avaliar se ocorreram alterações na síntese de proteoglicanas $\mathrm{e}$ colágenos, o que se pretende avaliar no futuro.

A análise da contagem de células dos animais, submetidos a movimentos de flexo-extensão contínua, utilizados nos experimentos, demonstrou que os animais exercitados à velocidade de $80 \mathrm{ciclos} / \mathrm{min}$. e grande amplitude apresentaram um aumento maior no número de células quando comparados aos animais exercitados à velocidade de 40 ciclos $/ \mathrm{min}$. em grande e pequena amplitude (Tabelas 3 e 4), o mesmo ocorrendo com os animais exercitados com velocidade de $80 \mathrm{ciclos} / \mathrm{min}$. e amplitude mínima quando comparados aos animais exercitados com velocidade de 40 ciclos $/ \mathrm{min}$. e; também, em grande e pequena amplitude (Tabelas 3 e 4).

Estes resultados demonstram que a amplitude, principalmente a velocidade, com que os exercícios foram realizados, influenciam diretamente as alterações observadas no número de células da cartilagem articular. Durante a realização do experimento por 15 dias, com duração de uma hora cada sessão de exercícios, a velocidade de 80 ciclos por minuto produziu 4.800 movimentos de flexo-extensão da pata direita, por dia, totalizando ao final do experimento 72.000 movimentos.

As respostas encontradas pela análise histológica das medidas de espessura dos animais submetidos a movimentos de flexo-extensão contínua 
foram estatisticamente significantes em relação ao seu respectivo controle (tabela 5 e 6).

KIVIRANTA et al. (1988), utilizaram uma esteira com inclinação de $15^{\circ}$ onde 14 cães corriam por cinco dias por semana em uma velocidade de 4 $\mathrm{Km}$ por hora, durante 15 semanas. Os resultados do experimento mostram que os exercícios de correr aumentam a espessura da cartilagem e a concentração de proteoglicanas, principalmente nas regiões onde as cargas são mais elevadas.

O mesmo padrão de resposta foi encontrado por BUCKWALTER (1995), quando estudou os efeitos da corrida moderada sobre a cartilagem articular em cães, estimulando-os a correr $4 \mathrm{Km}$ por dia, durante cinco dias por semana, perfazendo 40 semanas consecutivas. Após análises histológicas concluiu que houve aumento da espessura da cartilagem articular, acompanhado de elevação da concentração de proteoglicanas.

Apesar da confirmação de que o aumento da espessura da cartilagem articular está relacionado a estímulos mecânicos, ainda não há uma opinião predominante sobre o processo físiológico responsável por esse aumento.

HOLMDAHL \& INGELMARK (1948) citados por KIVIRANTA et al. (1988), relacionam o aumento da espessura da cartilagem articular de coelhos, após exercícios de correr, com aumento da substância celular e intercelular, como respostas adaptativas dos condrócitos .

KEMPSON et al. (1970), relatam que a espessura da cartilagem articular é diretamente correlacionada com o aumento da concentração de proteoglicanas e seu conteúdo de glicosaminoglicanas. Essa hipótese também é compartilhada por KIVIRANTA et al.(1988), que relatam um aumento da 
espessura da cartilagem articular como resposta ao exercício, devido a uma elevação do conteúdo de proteoglicanas na cartilagem calcificada, indicando, assim, um aumento da síntese de proteoglicanas pelas células do tecido cartilaginoso.

A quantidade de água é mais alta nos animais jovens e pode chegar em torno de $80 \%$ do peso desses animais. Essa grande quantidade de água é responsável por uma grande parte das propriedades físicas da cartilagem articular (THOMPSON JR \& ROBINSON, 1981). Como já citado anteriormente, a capacidade da matriz de reter um volume alto de água está associada às características hidrófilas das proteoglicanas.

MCDEVITT \& MUIR (1976), após estudarem as mudanças que podem ocorrer na cartilagem articular de cães, após lesão do ligamento cruzado anterior, sugerem que a diminuição dos agregados como: condroitina-6sulfatada, condroitina-4-sulfatada, keratina sulfatada, galactosamina, pode elevar a pressão osmótica, exercida pelas proteoglicanas e, como conseqüência, aumentar a espessura da cartilagem articular.

Isto está de acordo com as observações de BUCKWALTER (1995), quando relata que "sob cargas, a cartilagem se deforma e cria gradientes de pressão, abundância de fluidos, grandes fluxos potenciais, alteração no conteúdo de água, densidade de carga estabilizada, concentrações de íons e pressões osmóticas dentro da matriz".

Estes fatores citados como responsáveis pelo aumento da espessura da cartilagem articular de animais expostos a exercícios são as possíveis respostas às indagações feitas. É difícil determinar nos experimentos se o aumento da espessura se fez pelo inchaço da matriz ou pelo elevado peso 
molecular das proteoglicanas, pois haveria necessidade de outras formas de análise às utilizadas como método de avaliação.

A análise da espessura da cartilagem articular dos animais submetidos a movimentos de flexo-extensão contínua, utilizada em nosso experimento, demonstrou ainda que os animais exercitados a velocidade de 80 ciclos/min. e grande amplitude apresentaram um aumento maior da medida de espessura quando comparados com os animais exercitados a velocidade de 40 ciclos/min. e pequena amplitude (tabelas 05 e 06), o mesmo ocorrendo com os animais exercitados com velocidade de $80 \mathrm{ciclos} / \mathrm{min}$. e pequena amplitude quando comparados aos animais exercitados com velocidade de 40 ciclos/min. e pequena amplitude. (Tabelas 05 e 06).

Estes resultados demonstram que não só a velocidade com que os exercícios estão sendo realizados influencia nas alterações observadas, mas, também, a amplitude, pois a área de contato entre os côndilos femurais e o platô tibial torna-se maior, levando a um estresse mecânico.

Os princípios biomecânicos são válidos para este estudo de movimento de flexo-extensão contínua na articulação do joelho de ratos. Durante a extensão, as faces anteriores dos côndilos femurais podem suportar um peso, sendo que as faces posteriores só vão tocar a tíbia apenas na flexão máxima da articulação. Consequentemente, as faces posteriores dos côndilos femurais são mais exigidas quando da aplicação de exercícios em grande amplitude.

Segundo KIVIRANTA et al. (1988), o menisco distribui as forças de contato, poupando a área central dos côndilos das elevadas concentrações de estresse, dado esse também encontrado por MCDEVITT \& MUIR (1976), que estudaram as alterações da cartilagem articular de joelho de cães, após lesão do 
ligamento cruzado, onde encontraram alteração maior em uma área interna do côndilo medial que não era coberta pelo menisco, enquanto que as alterações foram menores nas áreas externas do côndilo medial e no côndilo lateral.

Provavelmente os dados encontrados nesta pesquisa indicam que a área do côndilo femural dos joelhos de ratos, definida para as análises histológicas, seja principalmente tocada quando ocorrido movimento de grande amplitude, deste modo caracterizando um volume de atrito maior, comparado ao movimento de pequena amplitude.

Estudos experimentais (MCDEVITT \& GILBERTSON, 1977; BUCKWALTER, 1995 ; NEWTON et al., 1997), têm sido realizados para confirmar a relação entre o uso da articulação e processos degenerativos. Ficou evidente nesta pesquisa que a cartilagem articular reage fortemente às alterações na sobrecarga articular. Os resultados encontrados são compatíveis com a idéia de que as concentrações de proteoglicanas são reguladas de acordo com a sobrecarga.

Como descrito anteriormente os componentes principais da cartilagem articular são: colágeno, condrócitos e proteoglicanas (MCDEVITT, GILBERTSON, MUIR, 1977; HARDINGHAM \& FOSANG,1992).

Com a metodologia empregada neste estudo, analisou-se o número de condrócitos e espessura da cartilagem articular de ratos. Sugere-se e pretende-se dando continuidade a esta linha de pesquisa, que sejam realizadas as análises dos níveis de síntese, depleção de proteoglicanas e a rede de fibras de colágeno. 
7. CONCLUSÃO 


\section{CONCLUSÃO}

Os resultados obtidos demonstram que:

1 - O equipamento utilizado é válido como modelo experimental, pois permite induzir, através de movimentos cíclicos e contínuos, alterações fisiopatológicas na cartilagem articular de pequenos animais, colaborando no estudo dos efeitos do uso moderado e excessivo da articulação.

2 - Pelo tipo de análises realizadas e resultados obtidos, não ficou demonstrada a interferência do fator de reposição alimentar, evidenciada pelos resultados das análises dos pesos.

3 - O efeito dos exercícios de flexo-extensão em 80 ciclos por minuto, e também em 40 ciclos por minuto realizados em grande e pequena amplitude, estimularam um aumento do número de células, sugerindo uma resposta reparativa ou adaptativa dos condrócitos, na área definida para análise da cartilagem articular do côndilo femural de ratos .

4 - O aumento da medida de espessura da cartilagem articular encontrada nos grupos experimentais não nos permite atribuir como processo de lesão, pois para tal há necessidade de análise de outros componentes da cartilagem articular, assim, definimos esta alteração como elevação de atividade metabólica e fator de proteção e adaptação. 
8. RESUMO 


\section{RESUMO}

Esta pesquisa teve como objetivo estudar as alterações da cartilagem articular dos côndilos femural de ratos, provocadas pela variação da amplitude de movimento e da frequência, utilizando-se uma máquina de movimentação de flexo-extensão contínua passiva.

Foram utilizados 24 ratos machos Wistar, divididos em quatro grupos: G1 (exercitados com 80 ciclos/minuto em grande amplitude), G2 (exercitados com 80 ciclos/minuto em pequena amplitude), G3 (exercitados com 40 ciclos/minuto em grande amplitude) e G4 (exercitados com 40 ciclos/minuto em pequena amplitude). Os animais pertencentes aos quatro grupos realizaram exercícios de flexo-extensão contínuas, diariamente, por 1 hora, através de um equipamento que atende aos princípios do mecanismo biela-manivela, o qual produz movimentos contínuos de flexo-extensão com grande e pequena amplitude, em frequência de 80 e 40 ciclos por minuto. Após 15 dias os animais foram sacrificados e de cada um a cartilagem articular do côndilo lateral do joelho direito foi retirada, incluída, cortada, corada com hematoxilina-eosina e analisada em fotomicroscópio.

Pela análise histológica observou-se aumento do número de células na área da cartilagem articular defínida para o estudo, nos quatro grupos exercitados, quando comparados ao respectivo controle. Os animais exercitados à velocidade de 80 ciclos por minuto e grande amplitude apresentaram um aumento no número de células quando comparados aos animais exercitados à velocidade de 40 ciclos por minuto em grande e pequena amplitude. O mesmo ocorreu com os animais exercitados com velocidade de 80 ciclos por minuto e pequena amplitude, 
comparados aos animais exercitados com velocidade de 40 ciclos por minuto e pequena amplitude.

Quanto à análise das medidas de espessura foi encontrado aumento em todos os grupos em relação ao respectivo controle. Os animais exercitados à velocidade de 80 ciclos por minuto e grande amplitude apresentaram um aumento da medida de espessura quando comparados aos animais exercitados à velocidade de 40 ciclos por minuto e pequena amplitude, o mesmo ocorrendo com os animais exercitados com velocidade de 40 ciclos por minuto e pequena amplitude.

Os dados demonstram que os exercícios de flexo-extensão contínua passiva estimulam aumento do número de células e aumento da espessura, não podendo ser atribuída como processo de lesão e, sim, como aumento de atividade metabólica e fator de proteção e adaptação. 
9. SUMMARY 


\section{SUMMARY}

This research had as objective to study the alterations of the articular cartilage of the knee of mices provoked by the variation of the movement width and of the frequency, using a machine of movement of passive continuous flexo-extension.

24 Wistar male mices were used, divided in four groups: G1 (exercised with 80 cycles/minute in great width), G2 (exercised with 80 cycles/minute in small width), G3 (exercised with 40 cycles/minute in great width) and G4 (exercised with 40 cycles/minute in small width). The animals belonging to the four groups accomplished flexo-extension exercises daily for 1 hour, through a equipment that assists to the principles of the "rod-cranck" mechanism, which produces continuous movements of flexo-extension with great width and small width in frequency of 80 and 40 cycles per minute. After 15 days the animals were sacrificed, the articular cartilage was collected, included, cut, colored with hematoxiline-eosine and analyzed in a photomicroscope.

For the histologic analysis an increase of the number of cells was observed in every area of the articular cartilage in the 4 exercised groups when compared to the respective control, that the exercised animals at the speed of 80 cycles/minute and great width presented an increase in the number of cells when compared the exercised animals at the speed of 40 cycles/minute in great and small width, the same thing happening with the animals exercised with speed of 80 cycles/minute and small width, when compared to the exercised animals of 40 cycles/minute and small width. 
As the analysis of the measures of thickness it was found an increase in all the groups in relation to the respective control. The exercised animals at the speed of 80 cycles/minute and great width presented an increase of the measure of thickness when compared the exercised animals the speed of 40 cycles/minute and small width, the same happening with the animals exercised with speed of 40 cycles/minute and small width.

The data demonstrate that the exercises of passive continuous flexo-extension stimulate an increase of the number of cells and increase of the thickness, not allowing us to attribute it as a lesion process, but as an increase of metabolic activity as a protection and adaptation factor. 
10. REFERÊNCIAS BIBLIOGRÁFICAS 


\section{0 - REFERÊNCIAS BIBLIOGRÁFICAS}

BADER, D. L. et al . The effects of selective matrix degradation on the shortterm compressive properties of adult human articular cartilage. Acta Biochim. Biophys, v.1116, p.147-54, 1992.

BUCKWALTER, J. A. Osteoarthritis and articular cartilage use, disuse, and abuse: experimental studies. J. Rheumat., v.22, n.1, sup.43, p. 13-15, 1995.

BEHRENS, F., KRAFT, E., OEGEMA JR, T.R. Biochemical changes in articular cartilage after joint immobilization by casting or external fixation. J. Orthop. Res., v.7, n.3, p.335-43, 1989.

CANDRALUCIO, R. A. , GILMER, J. R. S. Proliferation, regeneration, and repair of articular cartilage of immature animals. J. Bone Joint Surg. v.44A, n.3, p.431-55, 1962.

CATERSON, B. Changes in the metabolism of the proteoglicans from sheep articular cartilage in response to mechanical stress. Acta Bioch. Bioph., n.540, p.412-22, 1978.

CHROUSOS, G. P., GOLD, P. W. The concepts of stress and stress sytem disorders. J. Amer. Med. Assoc., v.267, n.9, p.1244 -52, 1992.

DUARTE, G. M. Fisiopatologia do exercício. In: DUARTE, G. M. Ergometria - bases da reabilitação cardiovascular, Rio de Janeiro: Cultura Médica, 1986, cap. 2, p. 3-6.

"NBR 6023/89 - ABNT 
FRANKS, B. D. What is stress? Quest, v.46, p.1-7, 1994.

GRIFFIN, J. F. T. Stress and imunity: a unifying concept. Vet. Immunol. Immunopathol., v.20, p.263-312, 1989.

HADLEY, N. A., BROWN, T. D., WEINSTEIN S. L. The effects of contact pressure elevations and asseptic necrosis on the long-term clinical outcome of congenital hip dislocation. J. Orthop. Res., v.8, p.504-13, 1990.

HARDINGHAM, T., FONSANG, A. J. Proteoglicans: many forms and many functions. FASEB J. v.6, p.861-70, 1992.

HARRISON, M. H. M., SCHAJOWICZ, TRUETA, J., Osteoarthritis of the rip a study of the nature and evolution of the disease. J. Bone Joint. Surg, 53B, p.598-626, 1953.

HOULI, J. A estrutura funcional das articulações. O mesênquima; a anatomia funcional osteoarticular. O cinésion. Folha Médica, v.89, p.95-108, 1989.

HOWELL, D. S. et al. The pathogeneses of osteoarthritis. Seminars. Arth. and Rheum., v.5, 1976.

JURVELIN, J. et al. Effect of physical exercise on identation stiffness of articular cartilage in the canine knee. Int, J. Sports Med., v.7, p.106-10, 1986.

Partial restoration of immobilization-induced softening of canine articular cartilage after remobilization of the knee (stifle) joint. J. Orthop. Res., v.7, n.3, p.352-58, 1989.

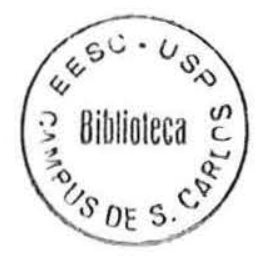


KEMPSON, G. E. Age-related changes in the tensile properties of human articular cartilage: a comparative study between the femoral head of the hip joint and the talus of the ankle joint. Acta Bioch. Bioph., n.1975, p.223-30, 1991.

, MUIR, H., SWANSON, S. A., FREEMAN, M. A. Correlations betwens stiffness and the chemical constituents of cartilage on the human femoral head. Acta Biochim. Biophys., v.1, n.215, p.70-77, 1970.

KNOPLICK, J. Revisão dos conhecimentos recentes da físiopatologia da cartilagem articular. Joint Cartilage a Revision of Physiopatology. Folha Médica, v.71, n.2, 1975, p.223-28.

KIVIRANTA, I. et al. Moderate running exercise augments glycosaminoglycans and thickmess of articular cartilage in the knee joint of young beagles dogs. J. Orthop. Res., v.6, p.188-95, 1988.

Weight bearing controls glycosaminoglycan concentration and articular cartilage thickness in the knee joints of young Beagle dogs. Arthrit. And Rheumatism., v.30, n.7, p.801-9, 1987.

KOBAYASHI, S., YONEKUBO, S., KUROGOUCHI, Y. Cryoscanning electron microscopic study of the surface amorphous layer of articular cartilage. J. Anat. v.187, p.429-44, 1995

LAINER, R. R. The effects of exercise on the knee joint of inbred mice. Anat. Rec., n.94, p.311-21, 1946. 
LOVÁSZ, G. et al. Effects of valgus tibial angulation on cartilage degeneration in the rabbit knee. J. Orthop. Res., v.13, n.6, p.846-53, 1995.

MANICOURT, D. H., PITA, J. C. Progress depletetion hialurônic acid Arthritis and Rheum., v.31, n.4, p.38-44, 1988.

MANKIN, H. J., LIPPIELLO, D. The turnover of adult rabbit articular cartilage. J. Bone Joint Surg., v.51-A, n.8, p.1591-600, 1969.

MAXIAN, T. A., BROWN, T. D. Chronic stress tolerance levels for human articular cartilage: two nonuniform contact models aplied to long-term follow-up of CDH. J. Biomech., v.28, n.2, p.59-66, 1995.

MCDEVITT, C., GILBERTSON, E., MUIR, H. Na experimental model of osteoarthritis; Early morphological and biochemical changes. J. Bone Joint Surg., v.59-B, n.1, p.24 -35, 1977.

, MUIR, H. Biochemical changes in the cartilage of the knee in experimental and natural osteoarthritis in the dog. J. Bone Joint Surg., v.58-B, n.1, p.94-101, 1976.

MICHALANY, J. Técnica Histológica em Anatomia Patológica. São Paulo: [s.n], 1980.

MOW, V. C. , RATCLIFFE, A. R., POOLE, A. R. Cartilage and diarthrodial joints as paradigms for hierarchical materials and structures. Biomaterials, v.13, p.67-97, 1992. 
NEWTON, P. M. et al. The effect of lifelong exercise on canine articular cartilage. Am. J. Sports Med., v.25, n.3. P.282-87, 1997.

OLSEN, E. B. et al. The effect of hyaluronic acid on cartilage in the immobilized rabbit knee. Acta Orthop. Scand., v.62, p.323-6, 1991.

PALMER, et al. Biomechanical properties of third carpal articular cartilage in exercise and nonexercised horse. J. Orthop. Res., v.13, p.854-60, 1995.

Site specific biochemical caracteristics of third carpal articular cartilage in exercised versus nonexercised horses. Am. J. Vet. Res., v.56, n.12, p.1570-6, 1995.

PICKERING, A. D. The concept of biological stress. In: Stress aud fish. Pickering Ed., Academic Press, New York, 1981.

SAAF, J. Effects of exercise on adult articular cartilage. An experimental study on guinea pigs with relevance to the continuous regeneration of adult cartilage. Acta Orthop.Scand. [suppl] v.7, p.1-86, 1950.

SCHWARTZ, M. H., LEO, P. H., LEWIS, J. L. A microestrural model for the elastic response of articular cartilage. J. Biomechanics, v.27, p.865-73, 1994.

SEIREG, A. , GERATH. An "in vivo"investigation of wear in animal joints. J. Biomechanics, v.8, p.169-72, 1975.

SELYE, H. A. Syndrome produced by diverse nocuous agents. Nature, v.138, n.1, p.32, 1936. 
SILVA, O. L., PIVA, N., FONSECA, J. C. P. Articular cartilage changes mechanically induced "in vivo". An experimental method approach in animals. Revista Brasileira de Pesquisas Médicas e Biológicas, v.11, p.277-81, 1978.

SMITH, L. R. et al. Rabbit knee imobilization: bone remodeling. Precedes cartilage degradation. J. Orthop. Res., v.10, n.1, p.88-95, 1992.

SOHN, R. S., MICHELI, L. J. The effect of running on the pathogenesis of osteoarthritis of the hips and knees. Clin. Orthop., v.198, p.106-9, 1985.

THAXTER, T. H., MANN, R. A., ANDERSON, C. E. Degeneration of immobilized knee joints in rats. J. Bone Joint Surg., v.47-A, n.3, p.567$79,1965$.

THOMPSON JR., R. C., HARRY, J. R. Current concepts review articular cartilage matrix metabolism. J. Bone Joint Surg., v.61-A, n.2, p.327-31, 1981.

VANDERLEI, L. C. M., MARCONDES, F. K., LANZA, L .L. B. e SPADARIBRATFISCH, R. C. Influence of the estrous cycle on the sensitivity to catecholamines in right atria from rats submitted to foot-shock stress. Can. J. Physiol. Pharmacol., v.74, p.619-27, 1996.

VAN DE KAR, L.D, RICHARDSON-MORTON, K. D., RITTENHOUSE, P.A. Stress: neuroendocrine and pharmacological mechanisms. Methods Achiev. Exp. Pathol., v.14, p.133-73, 1991.

VASAN, N. Effects of physical stress on the synthesis and degradation of cartilage matrix. Connect Tissue Res., v.12, p.49-58, 1983. 
VIEIRA, S. Como escrever uma tese. 2. Ed. São Paulo: Pioneira, 1994, 80 p.

YAN, G., KERONG, D. Degenerative Mechanism of articular Cartilage Induced by low stress. A morphological study. Chinese Med. J., v.108, n.11, p.835-8, 1995.

ZANESCO, A., SPADARI-BRATFISCH, R.C., BARKER, L.A. Sino-aortic denervation causes right atrial beta adrenoceptor dow-regulation. $\underline{\text { J. }}$ Pharmacol. Exp. Therap., v.280, n.2, p.677-85, 1997. 